\title{
Isabel de Santiago: una pintora quiteña del si- glo XVII
}

\author{
Inmaculada MARTín MARTíN
}

\begin{abstract}
RESUMEN. Con este artículo queremos aportar una novedad documental al panorama artístico quiteño de la segunda mitad del siglo XVII y principios del XVIII, divulgando el testamento de doña Isabel de Santiago, hija legítima del gran pintor Miguel de Santiago (ca. 1630-1706) y heredera de su taller. En este documento, hasta ahora inédito ${ }^{1}$, declara su dedicación al arte de la pintura, así como la de su esposo, D. Antonio Egas Venegas de Córdoba. Incluimos además la partida de casamiento de este matrimonio, aportando como dato novedoso la fecha de celebración del mismo. De igual manera analizamos un cuadro firmado, atribuido hasta este momento a Miguel de Santiago, llegando a la conclusión de que las iniciales no se corresponden con las de su nombre, modificando como consecuencia la atribución asignada al pintor durante tres siglos y medio.
\end{abstract}

Palabras clave: Isabel de Santiago, testamento, pintura barroca, Quito, siglo XVII, atribución, Miguel de Santiago.

ABSTRACT. With this article, we intend to contribute with new documental evidence to the Quitean artistic panorama of the second half of the 17th Century and the beginning of the 18th. This evidence consists in the publication of the last will of Mrs. Isabel de Santiago, legitimate daughter of Miguel de Santiago, the great painter (1630-1706), and heiress of his studio. In this document, only patially published before, she declares her full dedication to the art of painting, together with her husband, D. Antonio Egas Venegas de Córdoba. We also include the document that certifies this act of marriage, providing evidence about the date of this event. In the same way, we analyse a signed painting usually attributed to Miguel de Santiago, concluding that the painter's initials do not correspond with his name and, consequently, changing the painting three-century erroneous attribution.

Key words: Isabel de Santiago, last will, baroque painting, Quito, siglo XVII, attribution, Miguel de Santiago.

\section{ISABEL DE SANTIAGO. RESEÑA BIO- GRÁFICA}

Isabel $^{1}$ de Cisneros y Alvarado nació en Quito en la segunda mitad del siglo XVII

\footnotetext{
${ }^{1}$ El testamento de Isabel de Santiago fue hallado por Alfredo Costales Samaniego, dando su referencia en FernándeZ-Salvador y A. Costales SAMANIEGo, Arte Colonial Quiteño. Renovado enfoque y nuevos actores, FONSAL, Quito, 2007, pp. 227-228. En esta publicación
}

y murió en el año 1714 en la misma ciudad². Sobre la fecha de su nacimiento, de la que no hay noticia documental, deducimos que debió ocurrir en la década de 1660 a 1670. Fue hija legítima de Miguel de Santiago (ca.

únicamente transcribe algunos párrafos del documento.

${ }^{2}$ Nos referiremos indistintamente en éste artículo a Isabel con el apellido Cisneros, apellido de nacimiento, o Santiago, su apellido artístico. 
1630-1706), considerado el mejor pintor del siglo XVII en Ecuador y de doña Andrea Cisneros y Alvarado, originarios ambos de la ciudad de Quito y residentes durante toda su vida en el Alto de Buenos Aires, barrio de Santa Bárbara. Tuvo otros cuatro hermanos, Agustín Valeriano, Agustín Silvestre, del que sabemos que fue bautizado en la misma parroquia en el año $1677^{3}$, Bartolomé y Juana. Isabel recibió los apellidos de su madre, pues Miguel de Santiago, que fue hijo natural de Lucas Vizuete, indio, y Juana Ruiz, nacida en Quito, no dio a ninguno de sus hijos el apellido paterno ni el de adopción, sino el de su propia madre o el de su esposa Andrea, hija legítima de Francisco de Cisneros y de Juana Alvara$\mathrm{do}^{4}$.

$\mathrm{Al}$ parecer, Isabel Cisneros estuvo casada con Juan Merino de la Rosa, dato que no hemos podido confirmar al no hallar el documento de archivo citado por el autor de tal afirmación ${ }^{5}$; lo único que encontramos de este personaje es que fue nombrado portero mayor de la Audiencia de Quito por Real Provisión el veintidós de agosto de $1660^{6}$. Tiempo después, deducimos que tras

-

${ }^{3}$ Archivo Arzobispal de Quito, (a partir de ahora: AAQ), Libro de Bautizados y Confirmados de la Parroquia de Santa Bárbara. Marzo de 1645 a Junio de 1694. Libro 1, f. 88: "En dos de henero de seis sientos y setenta y sietel Baptisé y Puse Olio y Crisma a Agustín Silvestre, hijo de I Miguel de Santiago y de Andrea Cisneros fue su padrino don Francisco Vello de Portugal. Maestro Juan Molinero Roldán".

${ }^{4}$ R. PÉREZ PIMENTEL, Biografía de Miguel de Santiago, disponible en www.diccionariobiograficoecuador. com/tomos/tomo2/s7.htm (consultado el 7 de julio de 2008).

${ }^{5}$ Archivo Nacional de Historia de Ecuador, (a partir de ahora: ANE), Notaría I, Protocolos, f. 177, 1761: Testamento de Cristóbal Benegas de Córdoba, 7 de julio de 1716, citado por Costales en A. Costales SAMANIEGO, Arte Colonial Quiteño..., pp. 226. No hemos podido encontrar este documento en el ANE.

${ }^{6}$ Archivo General de Indias, (a partir de ahora: AGI), QUITO, 212, L. 7, ff. 216v-218r; El oficio de portero mayor de la Audiencia de Quito era otorgado mediante un nombramiento presidencial y no tenía el fallecimiento de Juan Merino, Isabel contrajo nuevo matrimonio el día 15 de enero de 1692 con el capitán don Antonio Egas Venegas de Córdoba, siendo padrinos en la ceremonia Miguel de Santiago y Andrea de Cisneros, padres de la contrayente, como consta en la partida de casamiento de ambos que hallamos en el Archivo Arzobispal de Quito? .

Fue también el segundo enlace para Antonio Egas Venegas de Córdoba, que era viudo de doña Catalina Tello de Meneses, natural de la Concepción de Chile, de la que había tenido al menos seis hijos: una llamada María, que ya estaba casada en 1677 con el regidor Juan de Vera Pizarro ${ }^{8}$ cuando bautizaron a su hermana Luciana Francisca Jerónima, de diez años de edad, de la que fueron padrinos su esposo y ella; otro fue Nicolás Javier Francisco, bautizado en 1669 a los ocho meses de nacido, y también, Catalina, Rosa y Antonio, que recibieron las aguas bautismales posteriormente?

salario ni renta: T. HerzoG, Mediación, Archivos y Ejercicio: Los Escribanos de Quito (siglo XVII), Ed. Vittorio Klostermann, Frankfurt am main, 1996, p. 149.

7 AAQ, Libro De Partidas De Casamientos..., de 1646 a 1795, L. 33, f. 42v (43): Reproducimos el documento en el Apéndice documental, $\mathrm{n}^{\mathrm{0}} 2$.

${ }^{8}$ Encontramos en el AGI algunos documentos que hacen referencia a este personaje: AGI, PANAMÁ, 56N.: confirmación del oficio de veinticuatro (Oficial Real) en la Audiencia de Panamá en 1617; AGI, PANAMÁ, 57, N. 65: nueva confirmación del mismo oficio.; AGI, PANAMÁ, 240, L. 20, ff. 114r-115r: solicitud para que se le permute el oficio de veinticuatro en Panamá por un regimiento en Quito.; AGI, QUITO, 213, L. 9, ff. 23v-25r: Real Provisión otorgando el oficio de regidor en Quito, despachada el 30 de septiembre de 1679; en este documento consta que ejercía de tesorero cuando optó al oficio de Regidor, y con avanzada edad estaba casado con la joven María, hija de Antonio Egas Venegas.

9 AAQ, Libro de Bautizados..., L.1, ff. 88, 92v y 93.; A. Flores CAAMAÑo, "El Testamento de Miguel de Santiago" en Gaceta Municipal, Año XXIII, n. 93, Quito, agosto 1939, p. 131: el autor, erróneamente, da el nombre de Feliciana como esposa del tesorero Juan de Vera Pizarro, español, en vez del de María. Aún cita otros 
De la unión de Antonio Egas con Isabel de Santiago nacieron cinco hijos legítimos, dos mujeres y tres varones: Agustín, María Mónica, Nicolás Fortunato, Antonio y María Tomasa. Los dos varones menores fueron religiosos profesos del convento de San Agustín, continuando la saga devocional de la familia al Obispo de Hipona, iniciada por su abuelo Miguel de Santiago, quien después de pintar una serie de cuadros sobre la vida del santo para el claustro del convento agustino de Quito, puso el nombre de Agustín a dos de sus hijos, y en su testamento expresó claramente el deseo de ser enterrado, con el hábito agustino por mortaja, en la iglesia del convento ade San Agustín de Quito ${ }^{10}$.

Isabel siguió los pasos de su padre y fue heredera de su taller, en el que habitualmente trabajaron su marido y ella. La artista ya era viuda cuando falleció su progenitor en 1706 y hasta su muerte, en 1714, continuó pintando. En su testamento dejó

hijos de Antonio Egas Venegas, como el presbítero Cristóbal José, el capitán Antonio de Padua y el padre Pedro, jesuita, pero no cita a María, Nicolás, Catalina y Rosa, de los que hemos hallado partidas de nacimiento, cuya referencia se aporta en esta nota. A. Costales cita acertadamente al doctor Cristóbal Egas, abogado de la Real Audiencia de Quito y a Antonio de Padua y a María Feliciana como hermanos del capitán Antonio Egas Venegas, a los que Flores Caamaño nombra como hijos: A. Costales SAMANiego, Arte Colonial Quiteño..., pp. 227.

${ }^{10}$ ANE, Notaría IV, Protocolos, núm. 54 y 55 (ahora 57 y 58), ff. 14 al 16. Testamento de Miguel de Santiago. Contamos también con el testimonio de Manuel de Cevallos y Velasco, escribano público de Provincia de la Audiencia y Chancillería Real de Quito que da fe de que cuando el martes 5 de enero de 1706 acudió a las casas de la morada de Miguel de Santiago, en el Alto de Buenos Aires del barrio de Santa Bárbara, le halló sin vida, su cuerpo tendido en el suelo en una sala sin puerta, con hábito de la religión del Gran Padre San Agustín por mortaja: A. FlORES CAAMAÑO, "El Testamento de Miguel de Santiago"..., pp. 117-132.; J.M. VARGAS, Miguel de Santiago. Su vida, su obra, Editorial Santo. Domingo, Quito, 1970. Apéndice con la información para la abertura del testamento cerrado que otorgó Miguel de Santiago, p. 127. información suficiente para saber que fue respetada en su profesión, ya que recibió numerosos encargos, concluyó obras de su esposo, también pintor, y realizó otras para cancelar algunas deudas dejadas por él. Pidió ser enterrada en el convento de Nuestra Señora de la Merced, próximo a su morada quiteña.

\section{ANÁLISIS FORMAL DEL TESTAMEN-} TO.

Esta tipología documental constituye una fuente para el conocimiento de diversos aspectos de la sociedad colonial, entre ellos los concernientes a la realidad de los personajes, que al enfrentarse a la proximidad de la muerte, dan a conocer las diversas situaciones de su vida. En las mandas testamentarias expresan su última voluntad, tocante a lo que desean que se haga no sólo con sus bienes, sino también con hechos y situaciones que han afectado su vida personal y a sus relaciones con el entorno.

El testamento de Isabel Cisneros y Alvarado responde, formal y jurídicamente, al modelo testamentario habitual a partir de la segunda mitad del siglo XVII, regulado en sus líneas básicas por las Partidas ${ }^{11}$. Va encabezado por la fórmula habitual de invocación: En el nombre de Dios Todopoderoso, Amen, seguida de los datos de identidad de la otorgante: su nombre, el de sus progenitores y el de su esposo, el capitán Antonio Egas Venegas con el que estuvo casada legalmente y con el que procreó como hemos dicho, cinco hijos legítimos.

${ }^{11}$ Partidas III, tit. XVIII, leyes 102-104. Las normas y regulaciones a que está sometida la constitución de los textos testamentarios en el mundo hispánico provienen de la Sexta Partida de Alfonso X el Sabio, dedicada enteramente a testamentos y herencias, constituyendo la base de toda la legislación vigente en España y América hasta el siglo XIX. 
Para ser digno de enterramiento en sagrado era necesario hacer confesión de fe, con declaración de creer en los misterios de la Santísima Trinidad y dictados de la Iglesia Católica, además de hacer expresa potestación de haber vivido y muerto como cristiano, pues dicho derecho estaba vedado a judíos y herejes ${ }^{12}$. La manifestante desarrolla su profesión de fe declarándose cristiana, creyente y practicante, miembro activo de la Iglesia Católica, invocando por abogada e intercesora a la serenísima Reina de los Ángeles, al Ángel de la Guarda y todos los demás santos de la corte celestial, para alcanzar el perdón de sus pecados y la salvación de su alma, fórmula que responde al modelo inscrito en la ortodoxia fijada en el Concilio de Trento. Al nombrar por su abogada e intercesora a la Reina de los Ángeles no sólo se adhiere a la fórmula ordinaria de advocación mariana, sino que expresa una devoción particular que sin duda le inculcó su padre, Miguel de Santiago, quien, por otra parte, es conocido que había realizado obras para la capilla del Hospital de la Caridad, dedicada precisamente a Nuestra Señora de los Ángeles ${ }^{13}$.

Siguiendo la lectura del documento de última voluntad de Isabel, ésta se declara enferma, pero en plena posesión de sus facultades mentales, condición necesaria para la validez legal del testamento ${ }^{14}$. Hace

${ }^{12}$ Partidas IV, tit. XVI, ley 4.

${ }^{13}$ ANE, Notaría IV, Protocolos, núm. 54 y 55, ff. 14 al 16: Testamento de Miguel de Santiago. Miguel de Santiago hace referencia a su relación artística con el Hospital de la Caridad, para cuya capilla realizó encargos pictóricos: "declaro que compré dos pilares de piedra que servían en el retablo de Nuestra Señora de los Ángeles, a Joseph de Luna, mayordomo, en treinta pesos, por cuya cuenta hice las pinturas que se hallan en su capilla, y no debo cosa alguna. Mando se traigan dichos pilares"

${ }^{14}$ Las fórmulas de invocación divina, profesión de fe, intercesión y aceptación de la enfermedad y muerte utilizadas por el escribano público que redactó el testamento son prácticamente idénticas a las utilizadas en el testamento de su padre, Miguel de Santiago, otorgado en los últimos días de 1705 y a las que se alusión a la concepción de la muerte como hecho natural y a la hora incierta en que se producirá, expresando su deseo de “dejar las cosas tocantes al descargo de mi consiencsia [sic] con toda claridad y distinsión", para continuar encomendando su alma a Dios. Isabel de Santiago pide ser enterrada en el convento de Nuestra Señora de las Mercedes, para lo cual había solicitado los permisos establecidos, que fueron concedidos $y$ confirmados por el Provincial de dicho monasterio, y ordena pagar los derechos correspondientes al cura de la parroquia de Santa Bárbara, de la que era feligresa. El convento estaba cercano a su lugar de residencia, pero no debía ser ese el único motivo de su interés por ser inhumada allí, ya que la relación familiar y artística con esta institución existía con anterioridad, como veremos en el apartado siguiente.

Isabel continúa desgranando su última voluntad, y dispone para las mandas forzosas un legado de a real cada una, más dos reales para los niños cautivos cristianos y un peso para la Casa Santa de Jerusalén. Pasa luego a enumerar las mandas voluntarias destinadas a sus devociones particulares, dejando dos reales para el Santísimo Sacramento de la Santa Iglesia Catedral y otro tanto para las beatificaciones o canonizaciones de las venerables madres Sor Juana de la Cruz, Mariana de Jesús y Sebastiana de Caso y Miranda ${ }^{15}$. Las dos beatas últimas eran familia de Isabel de Santiago por parte de su madre, Andrea Cisneros,

habían generalizado en el siglo XVII: ANE, Notaría IV, Protocolos, núm. 54 y 55, ff. 14 al 16.

15 J. MORÁn DE BUTRÓN, Vida de la beata Mariana de Jesús de Paredes y Flores, conocida vulgarmente bajo el nombre de la Azucena de Quito, Impreso en Madrid y reimpreso en Quito en la imprenta de V. Valencia, 1856. Además da noticias sobre la vida de Mariana de Jesús (1618-1645), y datos sobre Sebastiana de Caso, (ver pp. 71-80), nacida en 1626 y sobrina de Mariana, pues era hija de su hermana Jerónima. Pertenecían a familias nobles, los Flores, oriundos de Toledo y los Caso, de Asturias. 
prima segunda de Mariana ${ }^{16}$, por lo que no es de extrañar que formasen parte de su devoción particular; pero ha de tenerse en cuenta que según Morán de Butrón describe, la atribución de milagros y la devoción popular que suscitaron en Quito estas vírgenes en el siglo XVII fue general ${ }^{17}$. En cuanto a sor Juana de la Cruz, fue monja profesa en el monasterio de Santa Catalina de Quito $^{18}$

La redacción del testamento es ocasión, no sólo para ordenar las cosas del espíritu, sino también para aclarar y saldar las deudas materiales, obligaciones, asuntos pendientes y encargos no cumplidos, y así lo hace Isabel de Santiago que describe cuidadosamente lo cancelado hasta el momento y lo aún no resuelto, comenzando con los asuntos de su marido y de su padre. Es en este apartado del documento notarial es donde podemos constatar la actividad artística de Isabel que, en ocasiones, salda sus deudas con pinturas realizadas por ella misma.

Continúa haciendo declaración de los bienes dejados por su esposo e informa que constan en una memoria e inventario simples, ya que murió sin hacer testamento. También manifiesta que dejó una casa en el Alto de Santa Bárbara que se hallaba hipotecada en doscientos pesos por el maestro don Antonio de la Chica, que fue albacea testamentario de Miguel de Santiago, al que Isabel paga cincuenta pesos con un Santo Cristo de bulto que había heredado de su marido, posiblemente realizado por él

-

${ }^{16}$ J. M. VARGAS, Historia de la cultura ecuatoriana, Casa de la Cultura Ecuatoriana, Quito, 1965, p. 163; R. PÉREZ PIMENTEL , Biografía de Miguel de Santiago, op.cit.

${ }^{17}$ Ver la obra de MORÁN DE BUTRÓN, 1856, citada en la nota 15 .

${ }^{18}$ J.G. NAVARRO, Contribuciones a la Historia del Arte en el Ecuador, III, Litografía e imprenta Romero, Quito, 1950, pp.113-114. mismo, talla de la que no conocemos su paradero.

Prosigue la declaración de deudas de Isabel, señalando la que tenía con Manuel Jurado al que pagó ciento cincuenta pesos; a Sebastián Rosales le devolvió un sombrero de castor nuevo que no estaba pagado y a don Antonio Bera, además de pagarle catorce pesos de un débito, le cancela otro por dos lienzos que estaban a cargo de su marido difunto, con un cuadro de un Santo Cristo amarrado de medio cuerpo que era de los bienes de su padre ${ }^{19}$. Este Santo Cristo debe ser una pintura propiedad del museo mercedario de El Tejar en Quito, titulada "El Señor de la Columna", de la que hablaremos al tratar el tema de la relación de Miguel de Santiago con el convento de Ntra. Sra. de la Merced. Sobre otras hechuras encargadas por distintas personas, dice que dio cumplimiento a su entrega realizándolas ella misma, para lo cual tuvo que comprar materiales con parte de los bienes dejados por su esposo; también pagó cuarenta pesos que debía a Ignacio Miranda, pintando lienzos con dichos materiales.

El documento nos presenta a una mujer activa, enérgica y decidida, plenamente consciente de sus atributos y del valor del esfuerzo y trabajo personales, preocupada por dejar ordenados todos sus asuntos materiales, además de los espirituales, y por precisar el destino de sus bienes. Sus disposiciones testamentarias son claro testimonio de cómo Isabel de Santiago sufragó parte de las deudas familiares, pintando los cuadros que tenía pendientes su

19 AGI, QUITO, 213, L.10, ff.170v-174r: encontramos un Antonio Vera Pizarro nombrado por Real Provisión Fiel Ejecutor de la ciudad de Quito en 1717 y que podría tratarse del cliente que encargó las pinturas a Antonio Egas Venegas. Como habíamos visto anteriormente, un personaje llamado Juan Vera Pizarro, tesorero y después regidor de la ciudad de Quito, estaba casado con María, hija del primer matrimonio de Antonio Egas Venegas. Ver nota 8 y apéndice ㄲo 2. 
esposo, aclarando así muchas dudas sobre la actividad artística de la pintora, ya que hasta ahora no se habían aportado documentos que confirmasen su dedicación a este $\operatorname{arte}^{20}$.

No sabemos cuántos cuadros tuvo que pintar durante su viudedad, pero debieron ser bastantes, entre los encargos pendientes y los que tendría que realizar para subsistir, ya que es más que probable que su esposo hubiese recibido dinero adelantado por los encargos de obras de arte, dado que era práctica habitual que los artistas solicitasen dinero a cuenta del trabajo final, para adquirir lienzos, bastidores, pinturas y demás materiales necesarios, dejando deudas derivadas de las obras inconclusas. Por la declaración de Isabel, la tarea debió suponer gran esfuerzo para ella, pues sobre su empeño en rematar los encargos y obligaciones contraídas dice "...tocantes a distintas personas di cumplimiento a sus entregas, con mi sudor y trabajo, pintándolas, vendiendo algunos bienes del dicho mi marido para la compra de materiales..." ${ }^{\prime 21}$.

Entre sus deudas encontramos también una heredada de su padre, Miguel de Santiago, quien declaraba en su testamento deber a Ignacio Urasandi cinco pesos y dos lienzos de vara y media, con sus bastidores, disponiendo se le pagasen ${ }^{22}$; estos materiales los habría adquirido el pintor para su taller, ya que se trataba de lienzos en bruto.

Tras clarificar el capítulo de débitos, pasa Isabel a precisar los legados familiares de los que son beneficiarios sus hijos, provenientes tanto de los bienes de su marido

-

${ }^{20}$ Escéptico, Navarro reconoce que muchos escritores la han encomiado, pero afirma que no se conoce obra alguna de ella: J. G. NAVARRO, La Pintura en el Ecuador. S. XVI-XIX, Dinediciones, Quito, 1991, p. 83.

${ }^{21}$ ANE, Notaría IV, Protocolos, t. 63, ff. 127-129v, 1714: Testamento de Isabel Cisneros.

${ }^{22}$ ANE, Notaría IV, Protocolos, núm. 54 y 55, ff. 14 al 16. como de los suyos propios. Declara que su hijo Agustín había recibido ya parte del patrimonio a cuenta de la herencia correspondiente, hecho del que queda constancia en una memoria escrita en dos hojas de papel blanco que la otorgante desea se cosan a su testamento. También su hijo Nicolás Fortunato, fraile agustino, había recibido a cuenta de sus bienes: dos baúles y tres láminas pequeñas, que debían ser grabados artísticos, una cama con pabellón, dos almohaditas, frazada, sábana, colchón y sobrecama, cuatro hábitos viejos y vestuario nuevo cuando profesó, y cien pesos para los gastos de profesión, la mitad de ellos pagados de los bienes de su padre difunto, Antonio Egas, con un espadín de plata de valor de cuarenta pesos. Por lo que toca a su hijo Antonio, también fraile de San Agustín, gastó veinte pesos. En cuanto a sus dos hijas, Isabel atestigua no haberles dado bien alguno.

El testamento de Isabel de Santiago recoge asimismo las obligaciones contraídas por su esposo en vida, como la tutoría de Manuela Ramos, de la que se tuvo que hacer cargo a la muerte de Antonio Egas, alimentándola y vistiéndola. Durante ese tiempo, la susodicha falleció y para cubrir los gastos del funeral y entierro, Isabel hubo de vender al gobernador de Santa Bárbara una casita y un pedazo de tierra, que poseía la fallecida, por un total de noventa pesos. En descargo de su conciencia pide a su albacea que si sobrase dinero de los gastos, se le haga el sufragio del medio año.

La declarante describe a continuación sus posesiones, aludiendo primero a casas y tierras para referir a continuación otros bienes muebles, entre los que se cuentan una buena cantidad de cuadros y lienzos. Los bienes inmuebles de Isabel de Santiago consistían en las casas heredadas de su padre, libres de censos, empeños e hipotecas, y unas cuadras de tierras con un indio 
de padrón, que tenía concedido para trabajarlas. Poseía igualmente unas tierras con su cuarto cubierto de teja, bienes que quedaron de Miguel de Santiago, y que lega a su hijo Agustín. Asimismo era de su propiedad media cuadra de tierras en el barrio de San Sebastián que le dejó en herencia su padre $^{23}$, y que en el momento de testar estaba en tratos de vender a su prima Jacinta de Cisneros, que ya le había pagado once pesos a cuenta de los cien convenidos.

Es extraño que no haga alusión a los enseres domésticos, muebles, ropa de cama, utensilios y vestidos, como es habitual, pues consta que de su padre había heredado: una cama con pabellón, colchón, sábanas, un escritorio, una mesa grande, dos baúles, tres cajas de madera, un espejo, alguna pieza de plata, dos espadas y tres arcabuces, algunas ropas y enseres de calidad, lienzos, cuadros y libros, sin contar las casas y tierras, que es lo único que Isabel menciona. Es posible que los baúles y la cama que entregó a su hijo Nicolás al profesar como religioso fuesen parte de esta herencia, el resto tal vez lo vendió para ir sorteando problemas económicos, aunque indudablemente algún enser debía tener en las casas de su morada, por lo que su omisión puede ser un simple olvido quizás por su escaso valor ${ }^{24}$.

La enunciación de sus bienes se vuelve en cambio minuciosa cuando enumera las pinturas que obran en su poder, lo que nos vuelve a acercar a su condición de artista. Dice así:

“...doce lienzos de países con sus molduras en bruto y dichos países pinturas romanas. Un san Juan con su moldura negra. Dos

${ }^{23}$ ANE, Notaría IV, Protocolos, núm. 54 y 55, ff. 14 al 16. Miguel de Santiago declara en su testamento que las heredó de su madre, Juana Ruiz, y que compró las partes que correspondían a los demás herederos.

${ }^{24}$ ANE, Notaría IV, Protocolos, núm. 54 y 55, ff. 14 al 16. lienzos angostos de Nuestra Señora de los Dolores y san Juan. Dos lienzos de a vara de san Jerónimo y san Lorenzo. Seis o siete lienzos pequeños. Un lienzo grande de Nuestra Señora de la Concepción en bosquejo. Otro lienzo de una Magdalena. Otro de San Juan Bautista. Dos lienzos de medio cuerpo de tres cuartas, el uno de Filosofía y el otro de la Teología, un retrato del padre fray $B a-$ silio de Ribera de dos varas y media....". "...Item. Declaro que el licenciado Gregorio Lepe tiene en su poder dos láminas romanas de países y un libro de estampas de países de catorce hojas..., las dos láminas estaban en empeño de dos pesos y el dicho libro prestado..." 25

Cuando la pintora manifiesta poseer doce lienzos de países (paisajes) de pintura romana, nos hace recordar que su padre, al testar y enumerar sus bienes, también poseía "una docena de países de a dos varas, hechura de España" y suponemos, con cierta lógica, que podría tratarse de los mismos cuadros, coleccionados por el pintor y conservados celosamente por su hija, quien además de las pinturas conservaba un libro de estampas, varias láminas de grabados y un cuadro con tres ninfas, entregado en prenda al alférez Salvador Pabón; este último personaje le había hecho encargo de cuatro cuadros, dos de los cuales estaban entregados y los otros dos estaban a cargo de su primo, Nicolás Xavier de Goríbar, magnífico pintor discípulo de Miguel de Santiago. Esto nos da una visión de relación cercana entre ellos, ya que parecían colaborar en los encargos, hecho que nos reafirma en la buena calidad del trabajo de la pintora.

Finaliza la otorgante la disposición de su última voluntad declarando haber cumplido y pagado el testamento, mandas y legados, entierro y funerales, y señalando como herederos a sus hijos legítimos nombrados, y para el cumplimiento de sus disposiciones testamentarias, nombra albacea y tenedor de bienes al hermano de su espo-

${ }^{25}$ ANE, Notaría IV, Protocolos, t. 63, f. 127-129v, 1714: Testamento de Isabel Cisneros. 
so, el doctor Don Cristóbal Egas Venegas de Córdoba, presbítero, nombrándole a su vez tutor y curador ad bona de sus hijos menores de edad, con poder y facultad para administrar sus bienes conforme a derecho. En las últimas líneas de su testamento da rienda suelta a su preocupación por el bienestar y destino de los hijos menores, en especial por las hijas, a quienes procura favorecer con su última voluntad, ya que los hijos varones, de una u otra forma, habían percibido bienes del patrimonio familiar con anterioridad. Insiste particularmente en un tema que le inquieta, y manda que a su hijo Agustín se le descuente de la herencia todo lo percibido excluyéndole de cualquier derecho a la casa y tierras que tenía en propiedad, indicando que las destinaba a sus hijas, pues eran necesarias para su remedio y sustento.

El testamento se cierra con las preceptivas cláusulas revocatorias de cualquier otro anterior, escrito o de palabra, y lo fecha y firma ante el escribano de provincia de la ciudad de Quito, el 17 de mayo de 1714. A continuación el escribano da fe de conocer a la otorgante y de que ésta se encuentra en su entero juicio, memoria y entendimiento natural, y se señalan como testigos al maestro Marcos Morales, Nicolás de Goríbar y Juan Francisco de Nabarrete.

El documento tiene en primer lugar la firma manuscrita y la rúbrica de Isabel de Cisneros, seguida de la de Manuel de Cevallos y Velasco, escribano público y de provincia, rúbrica y la frase: "Ante mi, sin derechos, doy fee", y a su lado, una rúbrica.

La principal aportación de este documento notarial es que resuelve la duda sobre la dedicación a la pintura de su autora, demostrando que esta actividad le permitió subsistir tras la muerte de su esposo y su padre, pintores ambos, haciéndose cargo del taller y de los encargos tanto pendientes como nuevos. Debido a su condición de mujer es probable que no pudiese realizar los exámenes necesarios para la obtención de los grados que capacitaban para ejercer la pintura, comenzando como aprendiz y siguiendo como oficial, hasta llegar a maestro, lo que otorgaba jerarquía y reconocimiento social a los artistas; seguramente fue ignorada y tuvo que pintar a la sombra, primero de su padre y después de su marido, pero el testamento revela que fue una mujer con iniciativa, capacidad y reconocimiento, puesto que las obras de su mano no solo eran aceptadas como pago de deudas, sino que también eran objeto de encargos particulares.

\section{RELACIÓN DE ISABEL DE SANTIAGO CON EL CONVENTO DE NUESTRA SEÑORA DE LA MERCED DE QUITO}

Como queda constatado en su testamento, Isabel de Santiago pidió ser enterrada en la casa conventual de la Merced de Quito. Este hecho denota la estrecha relación familiar y profesional mantenida por la pintora y su familia con la institución quiteña, encontrando en primer lugar lazos familiares, pues el mercedario Antonio Ruiz de Alvarado era pariente cercano de su madre, Andrea Cisneros y Alvarado ${ }^{26}$. Por parte de su padre, había existido un compromiso adquirido con fray Antonio de Onramuño, comendador del monasterio, para el que había pintado cuatro lienzos de distintas efigies por el importe de cincuenta pesos, como hizo constar en su testamento $^{27}$. Ratificando la vinculación entre los de Santiago y la Merced, hoy se conservan en el museo conventual diversas obras del pintor, como "El Cristo de la Agonía", que podría ser el que dio origen a la leyenda del

${ }^{26}$ J.M. VARGAS, Miguel de Santiago..., 1970, p. 95.

${ }^{27}$ ANE, Notaría IV, Protocolos, núm. 54 y 55, ff. 14 al 16 . 
mismo nombre ${ }^{28}$; un cuadro de "El Divino Maestro" y otro del "Señor de la Columna"; un Cristo de tres cuartos que podría ser la obra a la que alude Isabel de Santiago en su testamento, como pago de una deuda. A mayor abundamiento, el historiador José Gabriel Navarro en la descripción del coro de la iglesia y las obras de arte que la decoraban, cita un cuadro que representa a "Santa Teresa con Jesucristo" que atribuye indiscutiblemente a Miguel de Santiago ${ }^{29}$; el padre Luis Octavio Proaño hace referencia a los cuadros de los Fundadores de las Órdenes Religiosas, como joyas de la pintura del inmortal maestro ${ }^{30}$, y por último, José María Vargas señala otras dos obras del pintor para la Merced, una "Apoteosis de María Inmaculada" que sitúa en el claustro del Tejar y una "Virgen con San José y el Niño Jesús", que según él, se hallaba en el palacio residencial cardenalicio ${ }^{31}$.

No era esta la única relación profesional de la familia con el convento mercedario, ya que el esposo de Isabel de Santiago, Antonio Egas Venegas, escultor, había recibido varios encargos de obras de arte para la iglesia, entre ellos una escultura del Señor del Amor que talló en 1699 por cien patacones $^{32}$, imagen que se encuentra en la hornacina central de un altar lateral de la

${ }^{28}$ R. PALMA, Tradiciones Peruanas, t.1, Montaner y Simón Editores, Barcelona, 1893, pp. 37-41; V. IGLESIAS, Miguel de Santiago y sus cuadrosde San Agustín, Tipografía de la Prensa Católica, $4^{\underline{a}}$ ed., Quito, 1922, pp. 418. En estas páginas el autor hace una relación de todas las leyendas que circulan sobre el pintor, citando autores y publicaciones y exponiendo argumentos convincentes para desmontar cada una de ellas

${ }^{29}$ J.G. NAVARRO, Contribuciones a la Historia del Arte en el Ecuador, II, Talleres Gráficos de Educación, Quito, 1939, p. 149.

${ }^{30}$ L. O. PROAÑO, "La Recolección Mercedaria de El Tejar. Su historia, su arte, su tragedia" en Boletín de la Academia Nacional de Historia, v. LXVII, 1984, 143-144, p. 152.

31 J.M. VARGAS, Miguel de Santiago..., 1970, p. 96.

32 A. Flores CAAMAÑO, “El Testamento..., 1939, p. 131. iglesia (Lám. 11). También había contribuido como pintor, en el año 1700, con un equipo de artistas, escultores, doradores y entalladores a la decoración del retablo principal de la iglesia, a cargo del maestro Tipán, alcalde y veedor de escultores desde 1690, pintando y decorando el interior del tabernáculo con tres ángeles, trabajo por el que cobró seis pesos ${ }^{33}$. Tras el fallecimiento de Antonio Egas, se le hizo la misa del medio año en la iglesia de Nuestra Señora de las Mercedes, por cuenta del pago de aquellos cuatro lienzos declarados en el testamento de Miguel de Santiago ${ }^{34}$. Algunos años después, su viuda, al justificar los gastos cubiertos con los bienes del marido difunto, dice que se emplearon setenta pesos en las misas del medio año y del año ${ }^{35}$. De las declaraciones de los otorgantes, padre e hija, se puede deducir que trabajaban en el mismo taller y que las ganancias obtenidas con el oficio de la pintura eran compartidas, empleándose indistintamente en las necesidades de uno $u$ otra.

\section{RELACIÓN CON EL CONVENTO DE SAN AGUSTÍN DE QUITO}

La vinculación artística con el convento agustino de Quito, en el que habían

${ }^{33}$ J. G. NAVARrO, Contribuciones...II, 1939, pp. 141142, que aporta como fuente el documento del Archivo Mercedario de Quito, Libro de Gasto y Recibo de la obra de la iglesia, ff. 12 y 12 v. Dice Navarro: "aquel retablo debió ser una obra artística de verdadero mérito; pues el padre Calderón escogió, para ejecutarlo, a los mejores obreros entre todos los que pudo conseguir, y que no fueron pocos. El maestro Tipán hizo el tabernáculo central con sus puertas bien labradas para alojar en él a un gran crucifijo, dos nichos laterales para las estatuas de la Virgen Dolorosa y del Apóstol San Juan y tres hermosas molduras para espejos con los que se debía adornar el remate; doró esté retablo el maestro dorador Bartolomé Nieto de Solís y decoró el interior del tabernáculo con tres ángeles pintados, el pintor don Antonio Egas Venegas de Córdova, yerno de Miguel de Santiago".

${ }^{34}$ ANE, Notaría IV, Protocolos, núm. 54 y 55, ff. 14 al 16.

${ }^{35}$ ANE, Notaría IV, Protocolos, t. 63 , f. $127-129 \mathrm{v}$, 1714. 
ingresado como religiosos dos de los hijos de Isabel, debió producirse a raíz de la actividad artística de Miguel de Santiago, su padre, que en 1656 fue el encargado de decorar el claustro monástico con una serie de cuadros sobre la vida del santo de Hipona basada en los grabados de Schelte Bolswert (1586-1659), uno de los mejores grabadores de la escuela de Amberes ${ }^{36}$. La presencia en los recintos conventuales de series iconográficas representando la vida del fundador de la Orden fue bastante frecuente en Hispanoamérica; a la vez que hacían exaltación de la vida y obras del santo, eran ejemplarizantes para los religiosos que habitaban el convento. La dirección de los trabajos y el contenido temático exigían profundos conocimientos teológicos, por lo que solían estar a cargo de algún religioso versado en el tema. El promotor de esta obra sobre la vida de san Agustín fue el padre Basilio de Ribera (1621-1678) ${ }^{37}$, provincial del convento agustino en Quito, que había conseguido los grabados en un viaje a Europa, llevándolos consigo a su regreso al

\footnotetext{
${ }^{36}$ Iconographia magni patris Aurelii Augustini, Ed. A. Ban, supervisado por Eugnio Warnelli, agustino, París, 1624: Esta serie fue encargada por el prior de los Ermitaños de Malinas, Georges Maigret, que redactó las leyendas explicativas en latín que están en las planchas. Esta serie de veintiocho estampas está en Le Cabinet des Estampes de la Biblioteca Nacional de París, de las cuales los números 21, "Los funerales de San Agustín" y 23, "Traslado de los restos de San Agustín de Cerdeña a Ticino" no son obra de Bolswert, sino del grabador Corneille Galle con el que solía colaborar. En cuanto a la colaboración de Bolswert y Galle, Cfr. F.W.H. HOLLSTEIN, Dutch an Flemish Etchings, Engravings and Woodcuts. T. III, Ámsterdam, s.d., p. 81 por J. Courcelle y P. COURCELle, Iconographie de Saint Augustin. Les Cycles du XVIe y XVIIe siècle, París, 1972, p. 45.

${ }^{37}$ Sobre el padre Basilio de Ribera, formación y cargos que ocupó ver E. TERÁN, Guía Explicativa de Cuadros Artísticos y Coloniales del Convento de San Agustín, precedida de las biografías del P. Basilio de Ribera y Miguel de Santiago, Imprenta Bona Spes, San Agustín, Quito, 1950, pp. 8-13.
}

convento quiteño ${ }^{38}$. El fraile agustino ideó, a partir de los grabados, un programa iconográfico en el que introdujo algunas modificaciones, como la leyenda, originalmente en latín, que sustituyó por otra en español, explicando la escena representada en el cuadro, además de las fuentes utilizadas: Possidonio, Próspero, Maburno, Ángeles, J. de la Vorágine y obras de S. Agustín (Confesiones, Sermones, Epístolas), entre otras. Las pinturas fueron patrocinadas por personajes de buena posición económica y social de la Audiencia de Quito, cuyo nombre y condición hizo constar al comienzo de cada inscripción; además, en dieciséis de los cuadros se añade el escudo o blasón nobiliario de otros tantos donantes, detalle que no está en el grabado. Fray Basilio de Ribera contrató para llevar a cabo esta empresa a un joven Miguel de Santiago, confiando plenamente en su capacidad artística, pues se trataba de trasladar las estampas de $18 \mathrm{x}$ $22 \mathrm{~cm}$ a unos lienzos de $310 \times 170$, tarea que culminó con maestría. El taller que dirigía, concluyó el proyecto durante el año 1656 y en esta empresa le acompañaron al menos los pintores Carreño, Bernabé Lovato y Simón de Valenzuela, discípulos suyos, además de otros cuyos nombres desconocemos, ya que, de seguro, contaría con aprendices y oficiales ${ }^{39}$.

Tal debió ser la gratitud familiar por este personaje, que su hija Isabel en el momento de testar ${ }^{40}$, declara entre sus bienes un retrato de fray Basilio de Ribera de dos varas y media, equivalente a una medida de $207 \mathrm{~cm}$., probablemente pintado por

${ }^{38}$ AGI, 1.16419 / PASAJEROS, L. 12, E. 992. Este documento contiene la solicitud de despachos solicitados por fray Basilio de Ribera para su regreso a Quito. En él, la Casa de Contratación de Sevilla emite los permisos necesarios para su embarcación.

39 J. M. VARGAS, El Arte Ecuatoriano, Biblioteca Ecuatoriana Mínima, J. M. Cajica, México, 1960, p. 189.

${ }^{40}$ ANE, Notaría IV, Protocolos, t. 63, ff. $127-129 \mathrm{v}$, 1714: Testamento de Isabel Cisneros. 
Miguel de Santiago, que quizás quiso conservar como reconocimiento a este religioso, gran impulsor de las artes, que le dio el primer espaldarazo como pintor. El vínculo con el convento agustino continuó a través de los hijos religiosos de Isabel, quien además, creemos que realizó alguna obra artística para el claustro de San Agustín, probablemente en vida de su padre, como más adelante expresamos en el apartado número 7 .

\section{OTROS ASPECTOS DE SU ACTIVIDAD ARTÍSTICA}

Si bien es importante la relación existente con los conventos agustino y mercedario de Quito a través de su padre y esposo, existen otros detalles y situaciones que nos van acercando cada vez más a la condición artística de Isabel.

Entre sus bienes había un libro de catorce hojas y varias estampas, láminas o grabados, que seguramente fueron utilizadas en el taller como modelo de aprendizaje y fuente de inspiración; debieron ser muy importantes para ella, pues en sus últimas voluntades se muestra especialmente preocupada por la recuperación de estos materiales, que estaban embargados $o$ en préstamo. Los grabados eran modelo para los pintores, que se valían de ellos, unas veces haciendo reproducción fiel, y otras, modificando la estructura compositiva o tomando simplemente alguna imagen o escena de los mismos. En ocasiones era la exigencia de los comitentes o clientes la que obligaba a los pintores a reproducir exactamente el tema, lo que mermaba la libertad del artista, pero aseguraba a quien costeaba la obra, ya fuese un cliente religioso o laico, que el encargo se ajustaba a su gusto estético y al programa iconográfico deseado.

Teniendo en cuenta las obras que Isabel de Santiago menciona en su declaración de bienes, advertimos que la temática de la pintura colonial de ese momento no estaba circunscrita únicamente a la religiosa, pues poseeía algunas representaciones de iconografía profana de la que ya teníamos antecedente en la pintura de su padre, con la serie de las Cuatro Estaciones, propiedad del Museo de Arte Colonial de Quito ${ }^{41}$. La autora conservaba doce lienzos de contenido paisajístico, los libros y grabados del mismo asunto mencionados en éste apartado, dos cuadros, uno de Teología y otro de Filosofía, otro con tres ninfas, y el retrato del fraile agustino Basilio de Ribera. En lo que se refiere a materia religiosa, encontramos representaciones aisladas de la Virgen y los santos y no escenas narrativas neo o vetero testamentarias; era dueña de una "Dolorosa" y un "San Juan", que podrían formar parte de un calvario para un retablo, pues se trataba de "dos lienzos angostos", una "Inmaculada", imagen de especial culto y devoción en Quito, así como un "San Jerónimo", patrono perpetuo de dicha ciudad y otras pinturas de "La Magdalena", "San Juan Bautista" y "San Lorenzo". Tenía además seis o siete lienzos pequeños, cuyo contenido desconocemos.

Sobre la adquisición de los materiales necesarios para el oficio de la pintura, es conocido que no era fácil en las colonias, ya que eran caros y escasos, aunque si bien en un principio se importaban de Europa, el elevado precio y la tardanza en la llegada de barcos, creó la necesidad de utilizar materiales autóctonos, obteniendo pigmentos de minerales y tierras ya conocidas en el mundo prehispánico, así como de plantas e insectos; los lienzos de lino, se sustituyeron, en muchos casos, por algodones más baratos de producción propia, como la sarga y el tocuyo, y los pinceles, se hacían con pelo

${ }^{41}$ Hoy día solamente quedan tres de los cuatro cuadros de la serie, "La Primavera", "El Otoño" y "El Invierno". Se desconoce el paradero del cuarto cuadro, correspondiente al Verano. 
de perro y otros materiales ${ }^{42}$. Isabel en su actividad artística, debió ocuparse elaborando los colores, cosiendo y tensando las telas y llevando a cabo todo el proceso preparatorio del cuadro hasta conseguir el producto final, desde la imprimación hasta la aplicación de aceites y barnices, para cuyo cometido de seguro necesitó ayudantes, aunque dada su precaria situación económica, es posible que fuese asistida por sus hijas, como ella debió hacer en el taller de su padre, del que aprendió.

Lienzos y bastidores solían adquirirse en el momento del encargo artístico, adelantando el comitente para ello parte del dinero convenido por la obra finalizada. $Y$ eso era lo que hacía nuestra pintora, según su testimonio, al igual que su marido Antonio Egas y su padre, Miguel de Santiago, pues entre las deudas de Isabel encontramos una heredada de este último, quien declaraba en su testamento deber a Ignacio Urasandi, cinco pesos y dos lienzos de vara y media, con sus bastidores, disponiendo se le pagasen ${ }^{43}$. Así mismo, para cancelar otras deudas y encargos dejados por su marido, tiene que vender alguno de sus bienes "para la adquisición de materiales"

Otro aspecto a tener en cuenta es que ni en el testamento de Miguel de Santiago ni en el de su hija hay mención de pertenecer a alguna cofradía gremial bajo la advocación de un santo patrono, como era habitual entre los artistas y artesanos de la época, ni se ha encontrado hasta ahora docu-

\footnotetext{
${ }^{42}$ Ver J.M. VARGAS, Miguel de Santiago, su vida..., 1970, pp. 104-110.; J. DE MESA y T. GISBERT, Historia de la pintura cuzqueña, I y II, Biblioteca Peruana de Cultura, Lima, 1982.; G. SIRACUSANO y J. E. BURÚCUA, "Polvos y colores en la pintura barroca andina. Nuevas aproximaciones" en ACTAS del III Congreso Internacional del Barroco Americano: Territorio, Arte, Espacio, Universidad Pablo de Olavide, Sevilla, 8-12 de Octubre de 2001.

${ }^{43}$ ANE, Notaría IV, Protocolos, núm. 54 y 55, ff. 14 al 16.
}

mento alguno que haga referencia a ello. La cofradía funcionaba como institución asistencial, prestando ayuda a sus integrantes en caso de necesidad grave, así como socorriendo a viudas y huérfanos y haciéndose cargo de los gastos del sepelio. Isabel de Santiago tuvo que superar dificultades económicas al quedarse viuda, pero ella misma manifiesta que sale adelante, como cabeza de familia, pintando para poder mantener a sus hijos.

\section{OBRAS ATRIBUIDAS A ISABEL DE SANTIAGO EN QUITO (ECUADOR)}

Hasta aquí creemos sobradamente demostrada la dedicación de Isabel de Santiago a la pintura, según las declaraciones que ella misma hace en su testamento. No obstante, desconocemos hasta el momento la extensión y la calidad de su obra. Únicamente tenemos constancia de un retrato realizado por ella en 1703 , el de sor Juana de Jesús, religiosa clarisa, en circunstancias que narra el padre Francisco Javier Antonio de Santa María en su "Vida prodigiosa de la Venerable Virgen Juana de Jesús" escrita en Lima en 1756:

"Algunas personas devotas de aquella sierva de Dios, dice, rogaron al capitán don Antonio Egas, aficionado a la pintura, que la retratase (estando ya muerta), quien aseguró bajo juramento no haber podido dar pincelada con acierto; $y$ conociendo no ser voluntad de Dios que pusiese mano en la obra, la dejó. Viendo que por ese medio no se podía lograr sus deseos, arbitraron el acomodarle en yeso, y tampoco lo consiguieron. Valiéronse finalmente de doña Isabel de Santiago, mujer del dicho don Antonio Egas y señalada en el arte, quien por las especies que le quedaron de las veces que le había visto, la sacó, si no con perfección, con alguna semejanza" ${ }^{\prime \prime 4}$.

\footnotetext{
${ }^{44}$ Citado por J. G. NAVARRO, La Pintura en el Ecuador..., 1991, pp. 82-83. Este testimonio nos parece digno de tener en cuenta, por su cercanía en el tiempo en que aconteció el hecho. Suponiendo que el autor no hubiese estado presente, sin duda el acontecimiento se
} 
Existen algunas atribuciones en la pintura colonial quiteña hechas por el profesor español de escultura J. González y Jiménez en $1877^{45}$, otras por el restaurador Carlos Barnas, que se estableció en Quito de 1935 a $1950^{46}$, que asigna la orla floral de la "Virgen de las Flores" a la pintora (Lám. 3), $\mathrm{y}$ muchas por algunos especialistas en arte cuyos nombres no se precisan y que encontramos citadas como suyas en varios trabajos del padre dominico José María Vargas, reconocida personalidad que goza de prestigio indudable como historiador y experto en arte $^{47}$. Si algunos autores han desconfiado de la actividad artística de Isabel de Santiago, otros, como Federico González, hacen elogio de ella diciendo que sobresalía en la dulzura y manejaba el pincel con admirable delicadeza ${ }^{48}$; de igual manera Jacinto Jijón y Caamaño (1890-1950) afirma que Isabel aprendió junto a su progenitor el arte de la pintura y que sus cuadros se caracterizan por un cúmulo de flores o animalillos que revelan "la pequeñez de su espíritu". Entendemos este comentario como halagador, haciendo referencia a su predilección por todas aquellas expresiones e imágenes que conducen al alma a la humildad y sencillez ${ }^{49}$.

Además de estas características, encontramos otras que definen su estilo, como la delicadeza en los rostros, que son ovala-

mantenía aun fresco en la memoria de sus contemporáneos. Lamentamos no poder reproducir la imagen de dicha pintura.

${ }^{45}$ V. IGLESIAS, Miguel de Santiago y ..., 1922, p. 22: Este personaje clasificó en 1877 los cuadros del convento de San Agustín de Quito.

${ }^{46}$ J.M. VARGAS, El Arte Ecuatoriano..., 1960, p. 201.

${ }^{47}$ J.M. VARGAS, Miguel de Santiago..., 1970, p. 97.; J. M. VARGAS, Arte Quiteño Colonial, Quito, 1944, p. 154.

${ }^{48}$ F. GONZÁlEz SuÁREZ, Historia General de la República del Ecuador, t. 7, Imprenta del Clero, Quito, 1903, p. 139.

${ }^{49}$ J. JIJÓN Y CAAMAÑO, Jacinto Jijón y Caamaño, Biblioteca Ecuatoriana Mínima, J. M. Cajica, México,1960, pp. 463-464. dos y finos, con encarnaciones nacaradas. Si la pincelada no es tan firme como en la pintura de Miguel de Santiago, la composición y la proporción en las figuras es correcta y resuelve con maestría el uso de la luz y del color. Quizás le falte la genialidad del maestro, pero no hay duda de que Isabel de Santiago fue una pintora de cierta calidad.

En varias de los obras atribuidas a Isabel de Santiago podemos hallar las características descritas por Jijón y Caamaño, entre ellas su maestría en la pintura de flores y su gusto por los pequeños detalles, como ocurre en el lienzo titulado "El hogar de Nazaret", del museo de San Diego de Quito, donde un rosal enmarca la composición en el lado derecho y un perrillo blanco acompaña al Niño, que ayuda a devanar el hilo a María, sujetando la madeja entre sus brazos; el gusto por el detalle y la anécdota también está presente en el pájaro parado en la cima del tejado del edificio del fondo o en los pendientes de perlas que adornan las orejas de la Virgen (Lám. 1). En "El Arcángel Gabriel", éste sujeta una cornucopia rebosante de flores que se van derramando por el suelo a su paso; tiene los brazos cubiertos con delicados velos y los vestidos, con estampados florales, se recogen y adornan con broches dorados cuajados de piedras, así como el cabello y el calzado (Lám. 2).

Un lienzo en el que intervinieron Miguel de Santiago y su hija Isabel es el de "La Virgen de las Rosas" (Lám. 3), en el que se representa a María con el Niño en brazos en el centro de la composición, sedente sobre un cúmulo de nubes grises, con un tenue resplandor circular como fondo; y enmarcando la escena, una guirnalda de flores de estilo flamenco, que sin ser multicolor, llena el cuadro de contrastes cromáticos. De esta obra conocemos dos versiones similares: la que mostramos, expuesta en el museo Padre Pedro Bedón del convento de Santo Domingo y otra, casi idéntica, pro- 
piedad del Museo de Arte Colonial, titulada "La Virgen de las Flores", ambas en Quito; los lienzos se debieron preparar al mismo tiempo, pues las piezas que lo conforman son muy similares, apreciándose por la posición de las costuras. La escena central es de Miguel de Santiago, pero la orla floral ha sido atribuida a Isabel por Carlos Barnas. Este restaurador, destaca la suave armonía de colorido de la escena central, frente a las duras sombras en rojo, amarillo y blanco de las flores, opinando que su representación no es placentera por el intenso colorido, que marca un fuerte contraste con el resto ${ }^{50}$. Para pintarlo se empleó técnica mixta al temple y óleo, y el modelo para la guirnalda debió ser algún cobre o grabado flamenco, ya que el tulipán no era una flor conocida en el país. El cuadro, restaurado por Barnas, es el perteneciente al Museo de Arte Colonial ${ }^{51}$.

Rasgos similares evidencia la obra de "San Antonio de Padua", en la que el estilo de Isabel se hace manifiesto en el delicado velo que cubre la cabeza de la Virgen, orlado de flores; en el suelo hay dos angelotes ante un libro, uno de los cuales dirige su mirada al espectador sujetando una rama de azucena, relacionada con la pureza y la

\footnotetext{
${ }^{50}$ J.M. VARGAS, El Arte Ecuatoriano..., 1960, p. 201: según Vargas, don Carlos Barnas era pintor y perito restaurador que se estableció en Quito de 1935 a 1950 y consagró su labor especializada a tratar algunas obras de los pintores coloniales, lo cual permitió conocer a fondo la técnica de cada uno de ellos. Antes había trabajado en el Museo de Amsterdam y realizado viajes de estudio por los museos de Alemania, Holanda, Italia, Francia e Inglaterra. En 1950 salió de Quito contratado por el Museo de Houston, Texas.

51 J.M. VARGAS, Miguel de Santiago..., 1970, pp.104106. El restaurador Carlos Barnas asegura que se encuentran tres versiones similares de este cuadro, y que aún hay un cuarto, que muestra solo la escena central, sin la orla de flores. Dice que el cuadro, formado por siete piezas de dos clases de tejido, estaba en muy malas condiciones, pues había sido lavado con jabón y se le habían aplicado grasas de mala calidad. Vargas cita como fuente: Revista "Américas", Marzo, 1968.
}

castidad, que junto al libro, son atributos del santo franciscano representado en el cuadro (Lám. 4). Al contemplar dos de los lienzos atribuidos a Isabel, el de "San Antonio de Padua", del Monasterio del Carmen de San José, y el de "El Hogar de Nazaret", del Museo Jijón y Caamaño, advertimos coincidencias compositivas, como las escenas de los ángulos inferiores izquierdo y derecho respectivamente: en el primero se trata de dos ángeles, y en el segundo, de el Niño Jesús y San Juan Bautista, que en ambos casos parecen entretenidos en animada conversación; igualmente, observamos como en las dos obras de igual título, "El Hogar de Nazaret", se repite el mismo perrito blanco, uno a los pies del Niño (Lám. 1) y otro a la derecha de la Virgen (Lám. 5) volviendo a encontrar en este último detalles similares, como dos ángeles afanándose sobre una cesta de flores o un gato sentado en el travesaño del banco de carpintero. El "Hogar de Nazaret" del museo Jijón y Caamaño (Lám. 5), es de igual formato que otro que representa a Santa Ana con la Niña María, del que lamentablemente no tenemos imagen, y que según José María Vargas, revelan un primer boceto de fondo que puede haber sido concluido por Isabel de Santiago $^{52}$.

En la representación de "La Virgen del Carmen" (Lám. 7) y de "La Inmaculada Eucarística con la Trinidad" (Lám. 8), existen claras analogías, sobre todo en las figuras trinitarias. En la segunda pintura, el original mostraba una Trinidad compuesta por tres figuras idénticas, y con posterioridad la escena se repintó, pues en el centro se trasluce con nitidez la tercera persona, correspondiente al Espíritu Santo, que era antropomorfa, situando en su lugar la paloma que le simboliza; así mismo ocurrió con la imagen del Padre, que fue sustituido por la figura de un varón de avanzada

\footnotetext{
52 J.M. VARGAS , Miguel de Santiago..., 1970, p. 97.
} 
edad. Es probable que Isabel de Santiago interviniese en la pintura de esta escena, pues en la Virgen, así como en el Padre Eterno, ambos sedentes, advertimos que la posición de las piernas y los pliegues del vestido se asemejan a los representados en los dos lienzos de "El Hogar de Nazaret" (Figs. $\mathrm{n}^{\circ} 1$ y no ${ }^{-}$). En otra de las obras atribuidas a ella, "La Virgen del Carmen" (Lám. 7), ésta aparece vestida con hábito carmelita acogiendo a sus hijas bajo el manto, sujeto a ambos lados por dos jóvenes ángeles portadores de ramos de flores que van derramando a sus pies: volvemos a encontrar en esta pintura la profusión de flores que tanto parece agradar a la pintora.

El museo franciscano Fray Pedro Gocial, en Quito, posee un lienzo de "La Virgen de la Alegría" (Lám. 6) que, según nuestra opinión, reúne características de la pintura de Isabel de Santiago. Tenemos una significativa referencia en el testamento de José Delgado, maestro pintor de la villa de Riobamba que testó en el año 1745 en Quito. Entre sus bienes artísticos mencionaba "una imagen de cañamazo de Nuestra Señora de la Alegría de la mano de Miguel de Santiago, que por ser de tal, la aprecio en dos pesos" ${ }^{\prime 53}$. Pues bien, nosotros nos inclinamos a pensar que dicho cuadro salió del taller de Miguel de Santiago, pero en él creemos observar la mano de su hija Isabel: el rostro suave de la Virgen, la representación del cabello y el sutil velo que lo cubre, los ángeles con los cestillos llenos de flores o la orla del manto, son detalles que se corresponden con su estilo.

Es probable que trabajase también en la ejecución de varios ángeles para uno de los retablos del crucero del Santuario de Guápulo, y en un lienzo de "San Gabriel", expuesto en el museo del mismo santuario,

-

${ }^{53}$ ANE, Protocolos, Notaría 1, año 1745. Citado por A. Costales, Arte Colonial Quiteño..., 2007, p.236. que por la estructura quebrada del marco en el borde superior, puede haber sido parte de un antiguo retablo. Estimamos que Isabel de Santiago debió colaborar en varios cuadros de su padre y su esposo, aportando detalles como flores, joyas, vestidos, broches, animales o paisajes. Existen coincidencias, por ejemplo, en varios broches o adornos representados en cuadros de Miguel de Santiago y en obrras atribuidos a ella.

Pero lo más significativo de la aportación que aquí hacemos sobre la obra de la pintora, es plantear como duda razonable la posible autoría de un cuadro, atribuido hasta ahora a su padre, Miguel de Santiago, cuestión que abordamos en el siguiente apartado.

\section{7. “LA CONTEMPLACIÓN MÍSTICA DE SAN AGUSTÍN": ¿UN CUADRO FIR- MADO POR ISABEL DE SANTIAGO?}

Este cuadro, titulado "Contemplación mística de San Agustín" o "San Agustín herido de amor por Cristo" propiedad del Museo Miguel de Santiago del Convento de San Agustín de Quito (Lám. 9), se ha considerado como la única obra firmada por Miguel de Santiago

Se trata de una pintura al óleo sobre lienzo, formado al menos por tres fragmentos unidos mediante costuras, restaurado y en buen estado de conservación. El formato se corresponde con los estándares de las pinturas del claustro monástico pero el pasaje de la vida de san Agustín no pertenece a la serie de grabados de Bolswert. En la actualidad el cuadro está expuesto en la sala del museo Miguel de Santiago de Quito y no en el claustro, aunque desconocemos si en algún momento estuvo colocado en los retablos dorados y tallados que sirven de soporte a la serie agustiniana.

Está compuesto por dos episodios narrativos desarrollados en diferentes 
ámbitos, delimitados por un grueso pilar. En la escena desarrollada al aire libre está Agustín vestido con el hábito de la Orden en actitud extasiada mirando al cielo donde aparece una inscripción hebrea en un rompimiento de gloria; como fondo, un paisaje andino con grandes montañas nevadas y cielos nubosos, donde combinan los colores fríos del cielo y las nieves con los ocres cálidos del valle por el que discurre un arroyo; entre el arbolado se divisa una construcción arquitectónica pintada de blanco. El pasaje que ocupa la parte derecha del cuadro se desarrolla en un recinto arquitectónico, en cuyo interior Cristo resucitado se aparece a san Agustín. El Señor, de medio perfil izquierdo, descalzo, con paño de pureza blanco y manto púrpura ondeando al viento, porta el lábaro en su mano izquierda y flexiona el brazo derecho mostrando la palma de la mano llagada; tiene el cabello castaño ondulado, barba afilada de dos puntas y una aureola brillante rodea su cabeza. San Agustín, arrodillado ante Él, le contempla absorto; viste hábito de su orden y capa pluvial de seda blanca ricamente recamada en oro con cenefa y remate perlado alrededor; tonsurado y barbado, tiene nimbo luminoso. De los estigmas de Cristo en pies, manos y costado, parten rayos luminosos que convergen en el corazón de Agustín. La mitra y el báculo descansan en el suelo embaldosado a la izquierda del santo y está separado del paisaje natural por lo que parecen dos escalones, formando una diagonal; en el muro se abre un ventanal enrejado. El artista introduce algunos elementos anecdóticos como una mariposa con sus alas abiertas descansando sobre el grueso pilar de fondo y una lámpara de tres brazos en los que luce una llama. En el ángulo derecho del cuadro está representado el escudo del donante y en la parte inferior una inscripción que dice:

"ESTE LIENZO DIO EL LICENCIADO DON VENTURA FALCONÍ, CURA Y VICARIO DE RIOBAMBA, COMISARIO
DE LA SANTA CRUZADA E INQUISICIÓN, EN QUE CRISTO N. SEÑOR SE APARECIÓ GLORIOSO A NUESTRO PADRE SAN AGUSTÍN PREGUNTÁNDOLE TRES VECES SI LE AMABA: RESPONDIO EL SANTO CON EL EJEMPLO DE LA LANZADA ENCENDIDA Y AQUE SI FUERA DIOS EL SANTO Y DIOS AGUSTINO, DEJAR AGUSTÍN DE SER DIOS PORQUE LO FUESE DIOS: ESTE ES SU VOTO EN ESTE CASO. JESUCRISTO N. REDENTOR, LE PREMIO DE ESTA FINEZA, LE MOSTRO SUS SANTAS LLAGAS CON RAYOS DE LUZ HAMBRIENTA EN SU CUERPO. MABURNO, CAP. $4^{\prime \prime 54}$.

En el ángulo inferior izquierdo aparece una firma manuscrita sobre una roca y a la derecha de la misma, restos de un tondo o cartela dorada que probablemente contenía el nombre del dorador, ya que aparece también en otros cuadros de la serie.

Hasta este momento se ha tenido por cierto que las iniciales autógrafas de la firma se corresponden con las letras " $M d S$ ", iniciales del nombre de Miguel de Santiago, pero si analizamos cuidadosamente la inscripción veremos que hay cuatro signos (Lám. 10): el que aparece en primer lugar

54 E. TERÁN, Guía Explicativa..., 1950, s/p. El P. Terán escribe en las páginas tituladas "AL LECTOR" la siguiente nota sobre las inscripciones de los cuadros de la pinacoteca: "Gran dosis de paciencia y de estudio ha demandado esta obrita, especialmente en lo tocante a la búsqueda de documentos biográficos y a la tarea de descifrar las inscripciones, casi borradas, ahora reconstruidas, puestas en lenguaje claro y correcto, de los Lienzos Coloniales". Terán introdujo algunos cambios al hacer las transcripciones, como se puede observar en algunas que se encuentran en condiciones de ser leídas.; J.M. VARGAS, Miguel de Santiago..., 1970, p. 35: en esta publicación encontramos una trascripción algo diferente: "Este lienzo dio el licenciado Don Ventura Falcón, cura y vicario de Riobamba, comisario de cruzada, en que en cuerpo Nuestro Señor se le apareció glorioso a Nuestro Padre San Agustín preguntándole tres veces si le ama, respondió el santo con el ejemplo de la lámpara encendida. De su voto en este caso Jesucristo Nuestro Redentor y en premio de esta fineza le imprimió de sus suntuosas llagas con rayos de luz sagrada en su corazón y le manifestó en un Éxtasis milagroso la visión de la esencia divina". 
sobre la roca, podría ser una $f$ (fecit) o $f r$ (fray); este primer signo no está enlazado con el segundo, pero es probable, si no se observa minuciuosamente, que ambos caracteres parezcan enlazados, lo que puede haber hecho pensar en una letra más compleja como es la $M$, todo ello animado por el deseo de encontrar una legitimación a la obra pictórica del admirado artista. Sin embargo, analizada esta firma paleográficamente nos atrevemos a asegurar que el segundo signo de la inscripción representa una $\mathrm{Y}$ o una $\mathrm{J}$, lo que nos daría la siguiente firma autógrafa: " $f Y d S$ ". De no ir errada nuestra apreciación, esto daría un vuelco a las investigaciones hasta ahora existentes, ya que algunos análisis pictóricos se han basado en esta obra para atribuir otras, de similares características, al pintor colonial ecuatoriano Miguel de Santiago.

A partir de esta consideración hemos de suponer que la pintura corresponde a la mano de Isabel $u$ otro discípulo de Miguel de Santiago, cuya primera inicial sea $Y$ o $J$. El análisis de la obra nos inclina a favor de la hija, ya que sigue las directrices del taller, utilizando con maestría los recursos en la composición y la proporción de las figuras, mostrando una figura de Cristo elegante, liviana, en cierto modo etérea, contraponiéndola a la otra más pesada y oscura, la postrada de san Agustín; en el cuadro se compensa la verticalidad del pilar y de la imagen de Cristo con las diagonales que parten de los rayos luminosos y el escalón que divide las dos escenas. Excelente utilización del claroscuro y de la fuente de luz, que inunda de resplandor la efigie de Cristo.

Formulamos la hipótesis de que este cuadro pudo ser pintado posteriormente a la serie realizada sobre la Vida de San Agustín basada en los grabados de Schelte Bolswert de los que hemos hablado anteriormente. En el claustro del convento agustino de Quito no encontramos repre- sentadas las veintiocho escenas de la vida de San Agustín reproducidas en estas estampas, pero no hay motivo para pensar que no se realizase la serie completa en 1656, momento en que Miguel de Santiago y su taller decoraron el recinto con las pinturas. Y no sólo fue su taller el que trabajó en el claustro, ya que fray Alonso Vera de la Cruz en la inscripción que se encuentra en la parte inferior del cuadro que representa al "Ángel Uriel" dice así:

"Este cherubin con la espada de fuego a la puerta del paraiso de este covto. dio y pinto por su qta. con otros doze lienzos el Pe. F. Alonso Vera de la Cruz"s5.

Es conocido que muchas de las pinturas que faltan se perdieron en los terremotos que se sucedieron uno tras otro desde que se construyó el convento. La erupción del volcán Pichincha, a cuyas faldas se encuentra la ciudad de Quito, ocurrida en 1660, hizo que muchos edificios se hundieran por el peso de la ceniza ${ }^{56}$. Del mismo modo se produjeron cuantiosas pérdidas en el terremoto de 1755 y finalmente, en el seísmo que tuvo lugar en 1859, la galería

\footnotetext{
${ }^{55}$ J.G. NAVARRO, Contribuciones...III, 1950, p. 93. Es curiosa la puntualización que hace el agustino: "por su cuenta", como queriendo aclarar que no pertenecía a otro taller.; Ídem, La Pintura en el Ecuador..., 1991, pp. 71-72. Otros colaboradores de Miguel de Santiago en la pintura del claustro de San Agustín, fueron Bernabé Lovato y Simón de Valenzuela, además de Carreño y el padre Alonso Vera de la Cruz, a quien considera buen pintor.

${ }^{56}$ Archivo Metropolitano de Historia (a partir de ahora: AMH), Actas de Cabildo Colonial de San Francisco de Quito, 1658-1663, v. XXXVI, pp. 232-260. En este documento el presbítero Juan Romero se encarga de hacer una relación de los hechos acaecidos por la erupción del Pichincha.; E. TERÁN, Guía Explicativa...., 1950, p. 12: refiere cómo a continuación de reventar el Pichincha, se produjo en 1662 un terremoto, según consta en la portada de la iglesia que se estaba llevando a cabo por mandato del P. Basilio de Ribera, de 1659 a 1665.; Ídem.: en las pp. 124-125 dice que en el terremoto de 1859 se destruyeron pinturas de la iglesia, de la cúpula y cincuenta y tres de la capilla del Señor de la Buena Esperanza.
} 
occidental del claustro de San Agustín se derrumbó al caer sobre ella la cubierta de la iglesia, destruyendo los marcos y cuadros que la decoraban ${ }^{57}$. Si tenemos en cuenta que para llenar las galerías se necesitan unos sesenta y cuatro cuadros y que en este momento los expuestos allí son cuarenta y tres, no todos basados en los grabados de $\mathrm{S}$. de Bolswert, podemos suponer que con el paso del tiempo se han realizado pinturas para completar la decoración e incluso para sustituir las perdidas, bien por accidentes como los descritos o por el deterioro sufrido con el paso del tiempo.

Deducimos de esto, que aunque Isabel de Santiago no pudo pintar en el claustro de San Agustín en 1656, primer momento de la decoración del recinto conventual, no hay que descartar que en el último cuarto del siglo XVII los comitentes agustinos solicitasen alguna obra al taller de su padre, encargándose Isabel de su ejecución. Desconocemos el paradero de los cuadros que Isabel menciona en su testamento, que quedaron en manos de cinco herederos. Pero consideramos que al menos dos de

${ }^{57}$ M. Villavicencio, Geografía de la República del Ecuador, Imprenta de Robert Craighead, New York, 1858, p. 224: “...en 1660, arrojó sobre la ciudad tantas piedras, arena $i$ ceniza, que muchas casas se hundieron con el peso....; N. CONCETTI, Memoria documentada de la Provincia agustiniana de San Miguel de Quito", Valladolid, 1916, en la Introducción: "Habiendo venido el movimiento de tierra del lado occidental, la cúpula se cayó hacia el convento y causó en éste los consiguientes destrozos. Destruyó la cubierta de la iglesia en la parte correspondiente a la nave de aquel lado y el claustro a ella contiguo, despedazando los marcos y cuadros de la galería que representaban escenas de la vida del Santo Obispo de Hipona".; V. IgLESIAS, Miguel de Santiago y..., 1922, p. 24, nota (1): No se removieron los escombros hasta 1870, once años después, por lo que todo lo que allí quedó, estaría totalmente destruido.; I. PINO y H. YÉPEZ, "Apuntes para un historia sísmica de Quito" en Centro Histórico de Quito: Problemática y Perspectivas, Serie Quito, v.1, 1990, p. 83. El terremoto de 1755 produjo importantes daños en toda la ciudad afectando de forma importante a las iglesias y conventos, entre ellos el de San Agustín. ellos, frailes agustinos, debieron donar al convento las pinturas que les correspondiesen del patrimonio familiar, entre las que se encontrarían, probablemente, obras de tres artistas: Miguel de Santiago, Isabel de Santiago y Antonio Egas Venegas.

\section{APÉNDICE DOCUMENTAL ${ }^{58}$}

$-1-$

1714, Mayo, 17. Quito.

TESTAMENTO DE DOÑA YSABEL DE CISNEROS

ANE, Protocolos, t. 63, ff. 127-129v.

/fol. 1/

La parte superior de las hojas 127, 128 y 129 del documento notarial están encabezadas por una cruz; debajo, "Vn Real", y están selladas con Sello Tercero de un real, años 1712 y 1713.

En el margen:

Testamento de Doña Ysabel de Cisneros.

Sacose un tanto y se entregó al hijo eclesiástico oy 13 de Diziembre de 1718.

En el nombre de Dios todo Poderoso Amen. Sea notorio a todos los que este testamento, última y postrimera voluntad bieren como lo otorgo yo, Doña Ysabel de Cisneros, vezina de esta ciudad Viuda del Capitán Don Antonio Egas de Córdoba y hija legitima de Miguel de Santiago y doña Andrea de Cisneros difuntos estando como estoy enferma y en cama, de la enfermedad que Dios Nuestro Señor a sido servido darm, e pero en mi entero juizio memoria y entendimiento natural, creyendo en el misterio de la Santísima Trinidad, Dios Padre, Dios Hijo y Dios Espiritu Santo, tres personas distintas y un solo Dios verdadero y en todo aquello que tiene, cree y confiesa la Santa Madre iglesia, cathólica romana, en cuia fee y creensia e vivido y protesto vivir y morir como catholica cristiana. Y para el transe de dar quenta de mis pecados a su divina Majestad, ynboco por mi abogada e yntercesora a la serenisima Reina de los Angeles María Madre de Dios y Señora Nuestra, al ángel de mi guarda y a todos los demás santos y santas de la corte celestial para que intercedan por mi alma ante su Divina Magestad, y alcansen perdón de mis pecados y porque el morir es natural a toda criatura viviente y la hora ynsierta, deseando dejar las cosas tocantes al descargo de mi consiencsia con toda clari-

\footnotetext{
${ }^{58}$ Las abreviaturas se han desarrollado, y los caracteres omitidos, se han añadido subrayados.
} 
dad y distinsion, hago y hordeno este mi testamento en la manera siguiente:

Primeramente encomiendo mi alma a Dios Nuestro Señor, que la crió y redimió con su graciosa sangre, muerte y pasión y el cuerpo a la tierra de que fue formado. El qual quiero y es mi voluntad sea sepultado en la yglesia del conbento de Nuestra Señora de las Mercedes redensión de cautibos de esta ciudad, debajo de las calidades contenidas en la escritura que tiene en su poder, confirmado y asetado por dicho conbento de su Provincial, a que se remite; $y$ se pagará al cura de la parrochia de Santa Bárbara /fol.2/ lo que le pertenesiere de dichos cargos por vivir en su feligresía.

Mando a las mandas forsosas y acostumbradas, a real a cada una de ellas, con que las aparto del derecho que pudieran tener a mis vienes = Para la redenpsión de niños cautibos cristianos, dos reales $=$ Para la caza Santa de Yerusaén, un peso = Para la cofradía del Santísimo Sacramento de la Santa Yglesia Catedral, dos reales $=$ Para las beatificaciones $o$ canonizaciones de las benerables madres sor Juana de la Cruz, Mariana de Jesús y Sebasthiana de Caso y Miranda, a dos reales.

Declaro que fui casada y velada segun horden de la Santa Madre Yglesia con el dicho capitán, don Antonio Egas y durante dicho matrimonio tubimos y procreamos por nuestros hijos legítimos a don $A u$ gustín = doña María Mónica = fray Nicolás Fortunat,o religioso profeso del conbento del gran Padre San Augustín = frai Antonio, asimesmo de dicha religión, y a doña María Thomasa Venegas de Córdo$b a, y$ extrayudisialmente, hizieron renuncia dichos religiosos, el mayor en mí y el otro en la dha doña Mónica su hermana. Declarolo así para que conste.

Declaro que el dicho mi marido murió sin hazer testamento, y quedaron por sus vienes los que constaáan de una memoria y ynventario simples que paran en mi poder, y una casa que está en este Alto de Santa Bárbara, la qual se hallaba ypotecada a la deuda de doszientos pesos a favor de maestro don Antonio de la Chica, con más sinquenta pesos que pagué a dicho maestro con el balor de un Santo Christo de bulto que quedó por vienes de dicho mi marido, y por que en el presio referido no se halla dicho maestro contento, se le darán veinte pesos de mis vienes.

Mas pagué por dicho mi marido, ciento y sinquenta pesos a Manuel Jurado de que tengo resivo, cuia paga la hize de su mesmos vienes; y por lo que toca a un sombrero de castor nuevo, lo bolbí por no estar pagado a don Sebasthián Rosales, con más un lienso de un Santo Christo amarrado de medio cuerpo que dí de los vienes de mi padre a don Antonio Bera por deuda del dicho mi marido, por dos liensos de obra que estaban a su cargo; y las más hechuras /fol. 3/ de que estaba a cargo del dicho mi marido tocantes a distintas personas, di cumplimiento a sus entregas con mi sudor y trabajo pintándolas, bendiendo algunos vienes del dicho mi marido para la compra de los materiales, como así mesmo pagué quareinta pesos a Ignasio de Miranda pintando liensos con dichos materiales; y con el balor de algunos vienes de dicho mi marido le hize por su alma los sufragios de medio año y el año, que en anbas funsiones se gastaron setenta pesos.

Declaro que en lo que a llebado el dicho mi hijo legítimo por quenta de su herensia paterna $y$ materna consta de una memoria que está en dos foxas escritas en papel blanco con tres renglones y medio borrados, y dicho papel suelto de carta suia que se coserán en este testamento; y para que conste en todos tiempos, por estar vivos los demás hijos, lo declaro así.

Declaro que lo que le e dado al dicho fray $\mathrm{Ni}$ colas Fortunato es lo siguiente $=$ de mis vienes, dos baúles, tres láminas pequeñas = Una cama que se compuso de pabellón, dos almaditas, fresada, una sábana, colchón y sobrecama, fuera de quatro ábitos viejos y bestuario nuevo quando profesó, y cien pesos en sus gastos de profesión, que la mitad de ellos fueron de los vienes del dicho mi marido, con un espadín de plata de balor de quarienta pesos.

$Y$ con el otro mi hijo religioso abre gastado veinte pesos= y a mis hijas no les e dado cosa alguna.

$Y$ por lo que toca a los demás vienes del dicho mi marido se an consumido, fuera de dichas pagas, en el sustento bestuario y eneñansa de escuelas que an tenido, como es público y notorio, porque como muger me e balido de ellos para dichos alimentos; declarolo así para que conste.

/fol. 4/

Declaro que debo al dicho don Antonio de Bera catorze pesos, mando se le paguen de mis vienes.

Más por deuda del dicho mi padre, estoy deviendo a la viuda de Urasandi ocho pesos, mando se paguen.

Declaro que el dicho mi marido fue tutor de Manuela Ramos, a la qual le pertenesía un pedaso de tierras con su casita que está en la frontera de la calle de la casa que poseo, y porraber muerto la dicha $M a-$ nuela Ramos, le hize su funeral y entierro por cuios costos me quedé con lo referido y bendí al governador de Santa Bárbara en nobenta pesos. Es mi voluntad, en descargo de mi consiensia, que en caso de que 
dichos gastos no hubiesen llegado a dicho presio, se haga por mi albacea moderadamente su medio año de sufragio, porque demás de dichos gastos, contribuy con la susodicha en alimentarla y bestirla. Declarolo así para que conste.

Ytten declaro por mis bienes las casas en que al presente bivo, que quedaron por fin y muertte del dicho mi padre legítimo, Miguel de Santiago, libre de senso, enpeño e hipoteca. Mas quedaron por bienes del dicho mi padre legítimo, unas cuadras de tierras que están una(tachado) media quadra más arriba de dicha caza, asimesmo libre de senso, con un yndio de padrón, como constará de los papeles que tengo en mi poder $=Y$ no enbargantte que el dicho mi hijo don Agustín Benegas tiene persevido todos los vienes declarados, que exseden a lo que le pudiera tocar, es mi voluntad se le entregue en propiedad unas tierras con su quarto cubierto de teja, que hasimesmo quedaron por bienes del dicho mi padre, que están en dicho alto.

Declaro que en el barrio de San Sebastián tengo media quadra de tierras que quedó de la dicha mi madre, que aunque su balor era de sien pesos tengo echo trato de venderla con Doña Jasintta de Cisneros, mi prima. Y por quenta me tiene dados onse pesos, y lo demás se me debe y se cobrará /fol. 5/ por mis bienes, otorgándose la benta por mi albacea.

Declaro que en poder del alferes Salbador Pabón tengo un lienzo de tres ninfas solamente, por dos lienzos de a bara que le [he] de entregar, que están a cargo de Nicolás de Goríbar, que aunque tengo entregados otros dos, se rrestan los referidos, entregándosele dicho resto; se rrecaudarán por mis bienes dichas ninfas.

Más declaro por mis bienes los siguientes: Doze liensos de payses con sus molduras en bruto $y$ dichos países pinturas romanas $=U n$ san Juan con su moldura negra $=$ Dos liensos angostos de Nuestra Señora de los Dolores y san Juan $=$ Dos liensos de a bara de san Gerónimo y san Lorenzo = Seis o siette liensos pequeños = Un lienso grande de Nuestra Señora de la Consepsión, en bosquejo = otro lienzo de una Madalena $=$ otro de san Juan Bautista $=$ Dos liensos de medio cuerpo de tres cuartas, el uno de Filosofía y el otro de la Teología = un rretrato del padre frai Basilio de Ribera de dos baras y media $=Y$ para cumplir y pagar estte mi testamento, sus mandas y legados, dejo y nombro por mi albacea testamentario y tenedor de vienes al doctor don Christóbal Egas Benegas de Córdova, presbitero, a quien doy el poder y facultad necesario en derecho para que disponga de mis bienes conforme su obligación.
Yttem declaro que el lizenciado don Gregorio Lepe tiene en su poder dos láminas romanas de paises y un libro de estanpas de países de catorze foxas, que los tubo por rrazón de que las dos láminas estaban en enpeño de dos pesos, y dicho libro prestado, y no le debo cosa alguna, más sea de recaudar un patacón que me debe.

Y cumplido y pagado este mi testamentto, sus mandas y legados, entierro y funerales, en el remanentte de mis bienes que quedare, dejo y nombro por mis herederos a los dichos mis hijos nombrados, descontandose en dicho don /fol. 6/ Agustín todo lo que tiene persebido, sin que pueda tener derecho ni acción a dicha caza, que tiene [sic] y poseo, y tierras, por quedar estos vienes para mis hijas, que necesitan su rremedio y alimentos $=Y$ asi mesmo nombro por tutor y curador ad bona de los hijos menores, al dicho doctor don Cristóbal, para que los administre conforme a derecho y con la facultad que por él esta concedida.

Con lo qual revoco y anulo y doi por ningunos $y$ de ningun valor ni efecto otros qualesquiera testamentos, codisilo,s poderes que aya dado por escrito o de palabra, para que no balgan ni hagan fee judicial ni extrajudicialmente; y solamentte quiero balga éste por tal última voluntad o por aquel ynstrumentto que permita el derecho en descargo de mi conciencia, que es fecho y otorgado ante el preente escrivano de Provinsia en esta ciudad de Quitto en diecisiete de Maio de setecientos y catorze; y yo el dicho escrivano doy fee conosco a la otorgante, que otorgo este su testamentto estando en su entero juicio, memoria y entendimientto natural, al parecer, según las razones consertadas que habló y dispuso, quien dijo que así lo otorgaba y firmó, siendo testigos el maestro Marcos Morales, Nicolás de Goríbar y Juan Fransisco de Nabarrete.

Maria Ysabel de Cisneros / Rúbrica

Ante mi Manuel de Cevallos y Velasco / Rúbrica

Sin derechos doy fee / Rúbrica Escribano Público y de Provincia

$-2-$

1792, Enero, 15. Quito. PARTIDA DE CASAMIENTO DE DOÑA ISABEL CISNEROS Y ALVARADO Y DON ANTONIO EGAS DE CÓRDOBA.

AAQ, Libro de partidas de casamientos de españoles y mestizos de la parroquia de Santa Bárbara. Años de 1646 y hasta el de 1795. Libro 33, f. $42 \mathrm{v}$. 
Margen izq: Anttonio con Isabel.

"En quince de henero, ano de nobenta y dos, casé y belé, hechas las amones / taciones que manda el Santo Concilio de Trento, Yn gratie ecclesie según orden de Nuestra Santa Madre/ Iglesia, a don Anttonio Egas de Córdoba con doña Ysabel de Sisneros y Albarado; / fueron padrinos Miguel de Santiago y Andrea de Sisneros; testigos: el licenciado / Marcos Meléndes, el licenciado Juan de Anguieta y el licenciado Pedro de Yepes=, Bachiller Augustin de Cepulbeda".

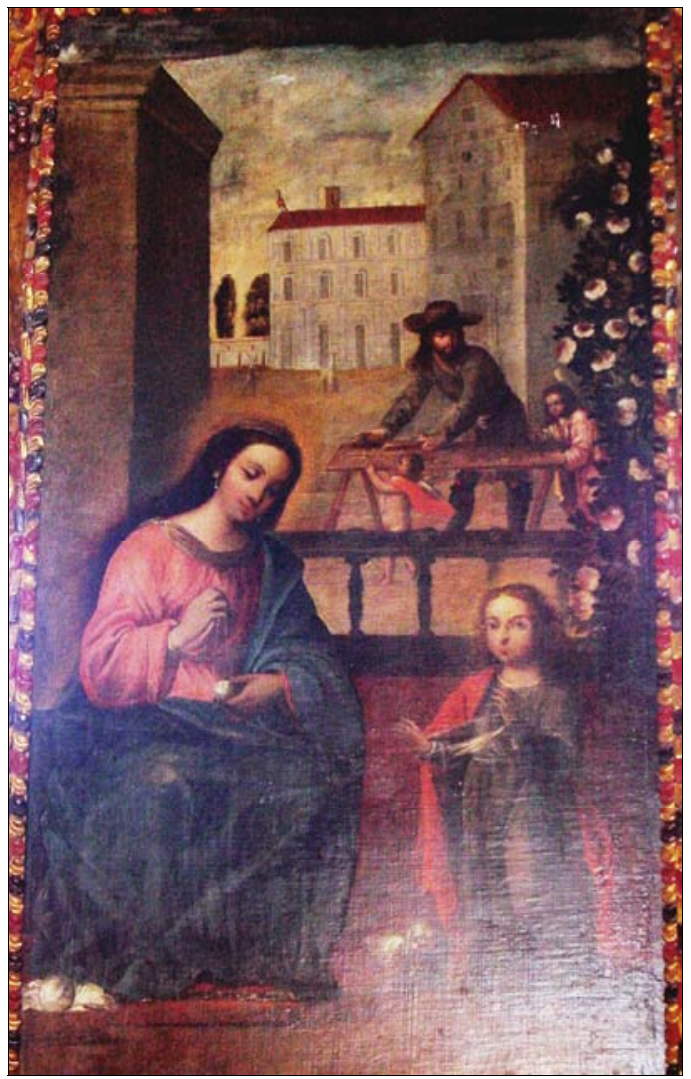

- Lám. 1. "El hogar de Nazaret". Atribuido a Isabel de Santiago, segunda mitad del siglo XVII, principios del XVIII. Museo del Convento de San Diego. Quito (Fot. de la autora).

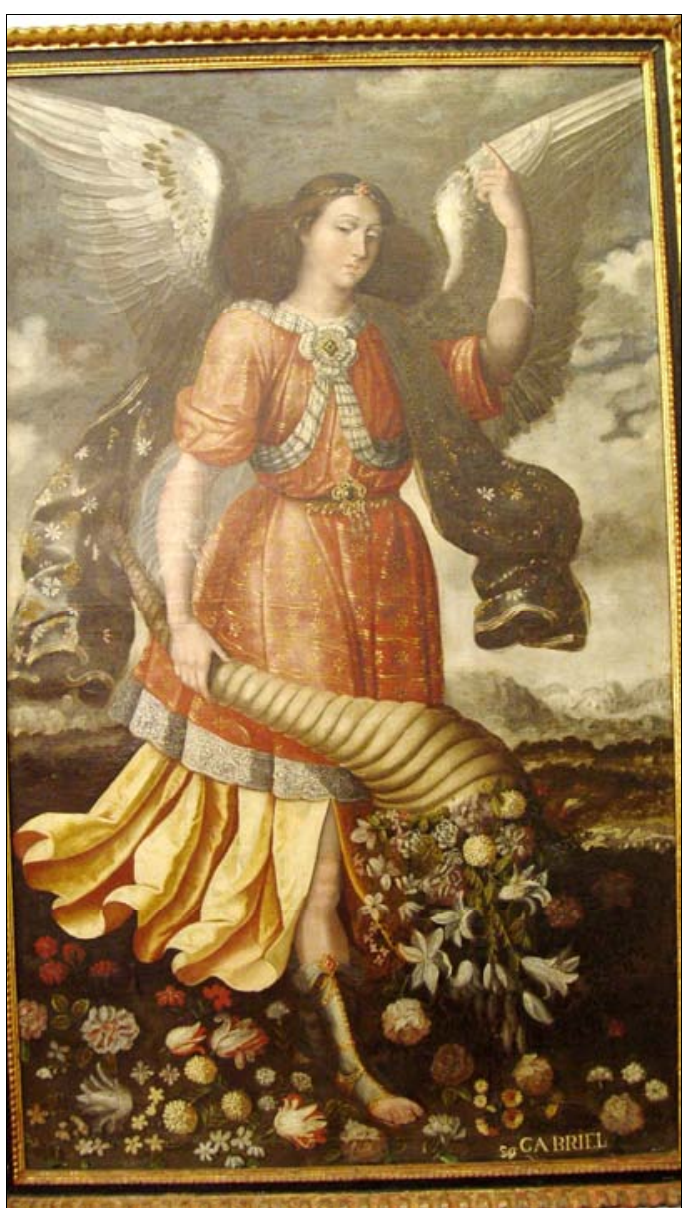

- Lám. 2. "Arcángel Gabriel". Atribuido a Isabel de Santiago, segunda mitad del siglo XVII, principios del XVIII. Museo Fray Pedro Gocial. Quito. Fotografía de la autora. 


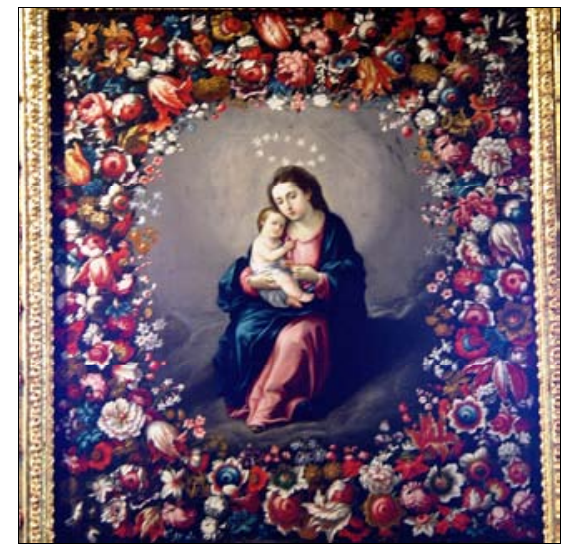

- Lám. 3. "Virgen de las Rosas". 138 x 156 $\mathrm{cm}$. Orla floral atribuida a Isabel de Santiago, $2^{\underline{a}}$ mitad del siglo XVII, principios del XVIII. Museo Padre Pedro Bedón. Quito (Fot. de la autora).

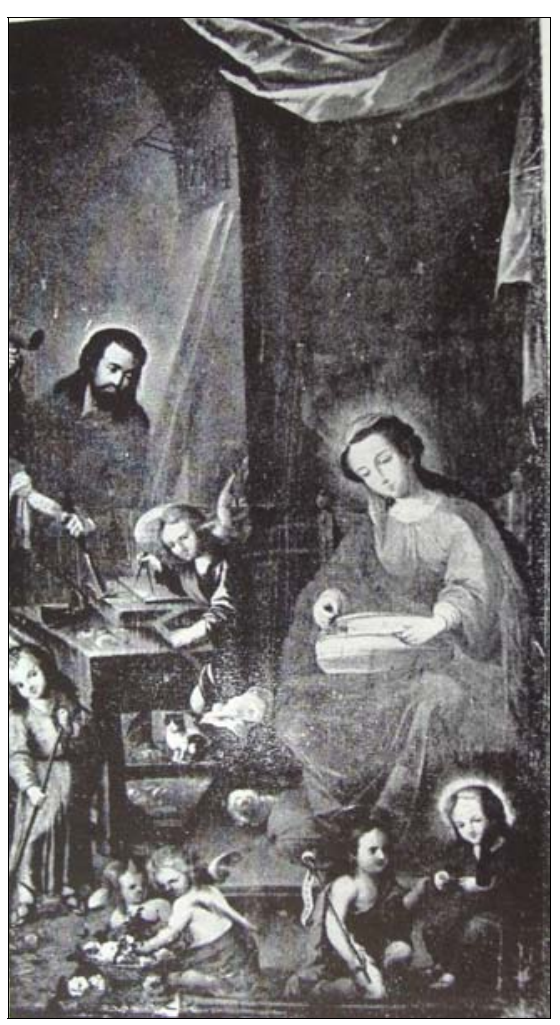

- Lám. 5. "Hogar de Nazaret". 205 x 105 $\mathrm{cm}$. Museo Jijón y Caamaño. Quito. Atribuido a Isabel de Santiago. $2^{\mathrm{a}} \mathrm{mitad}$ del siglo XVII, primer tercio del XVIII. Imagen tomada del libro de de J. M. VARGAS, Museo Jijón y Caamaño y el patrimonio artístico, Ed.de la Universidad Católica, Quito, 1978, p. 23.

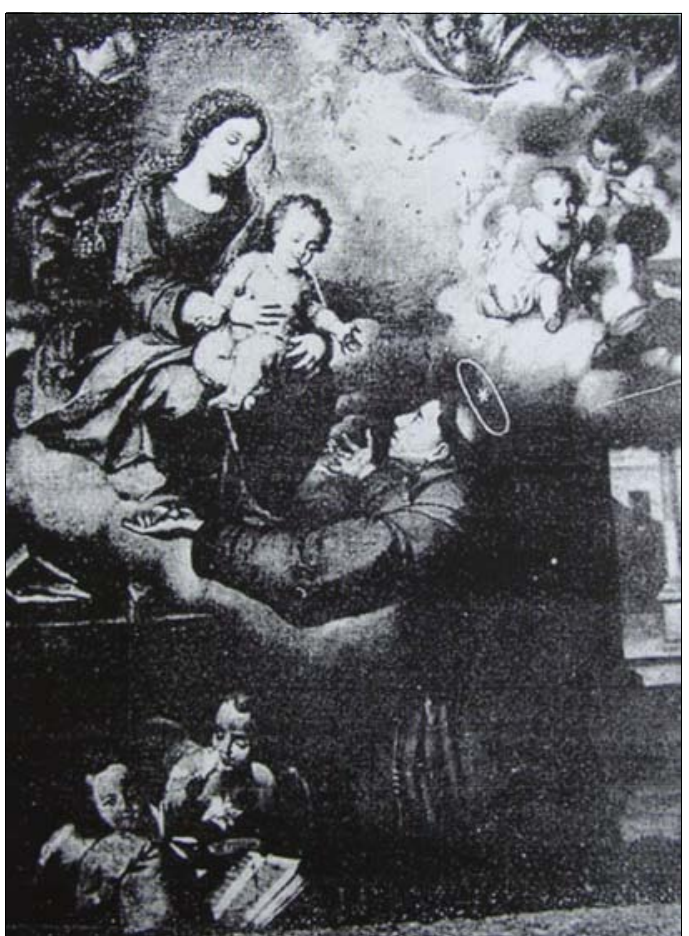

- Lám. 4. "San Antonio de Padua". Atribuido a Isabel de Santiago, segunda mitad del siglo XVII, primer tercio del XVIII. Monasterio del Carmen de San José. Quito. Imagen tomada del libro de J. M. VARGAS, Arte Quiteño Colonial..., 1944, índice de imágenes: n. LXV.. 


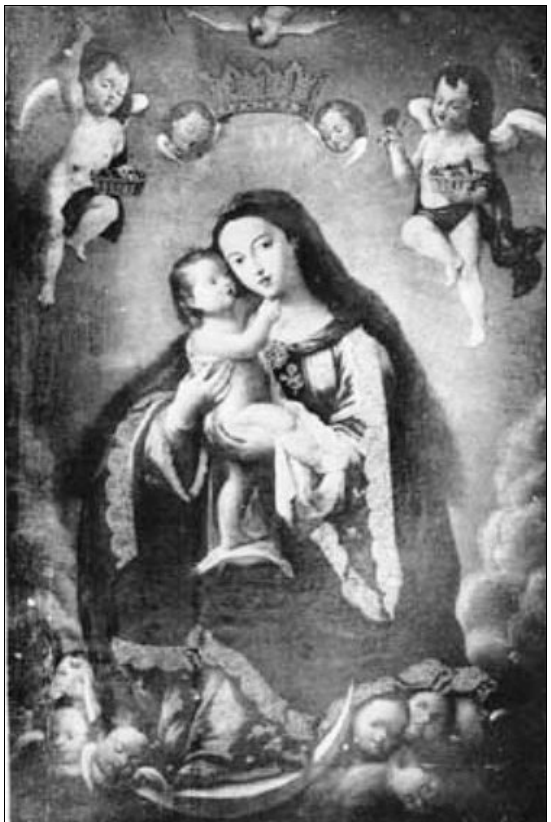

- Lám. 6. Virgen de la Alegría. Museo Fray Pedro Gocial. Quito. Atribución: Escuela Quiteña, siglo XVII. Imagen tomada del libro de J. G. Navarro, Contribuciones a la Historia del Arte en el Ecuador, I, Tipografía y Encuadernación Salesianas, Quito, 1925, lam.XV, p.62. Según nuestra opinión, este cuadro se corresponde con el estilo y las características de Isabel de Santiago.

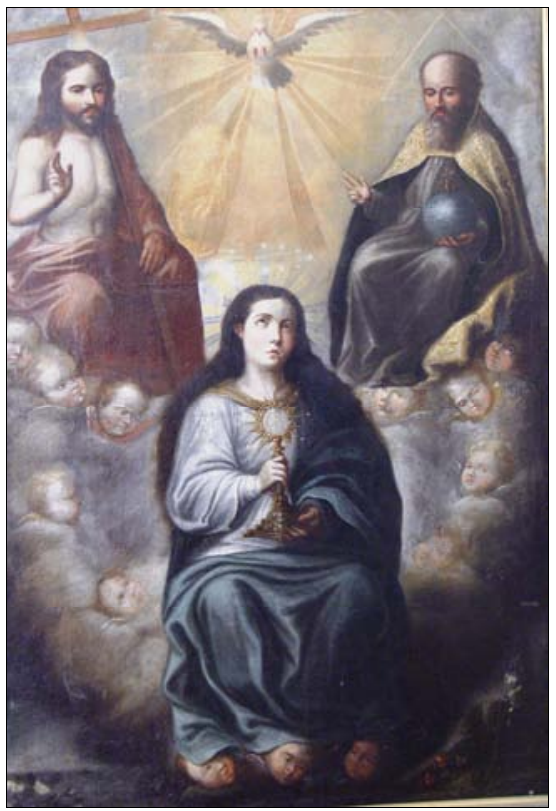

- Lám. 8. "Inmaculada Eucarística con la Trinidad". Atribuida a Miguel de Santiago. $2^{\mathrm{a}} \mathrm{m}$. del s. XVII. Museo Fray Pedro Bedón. Quito. Fotogr. de la autora.

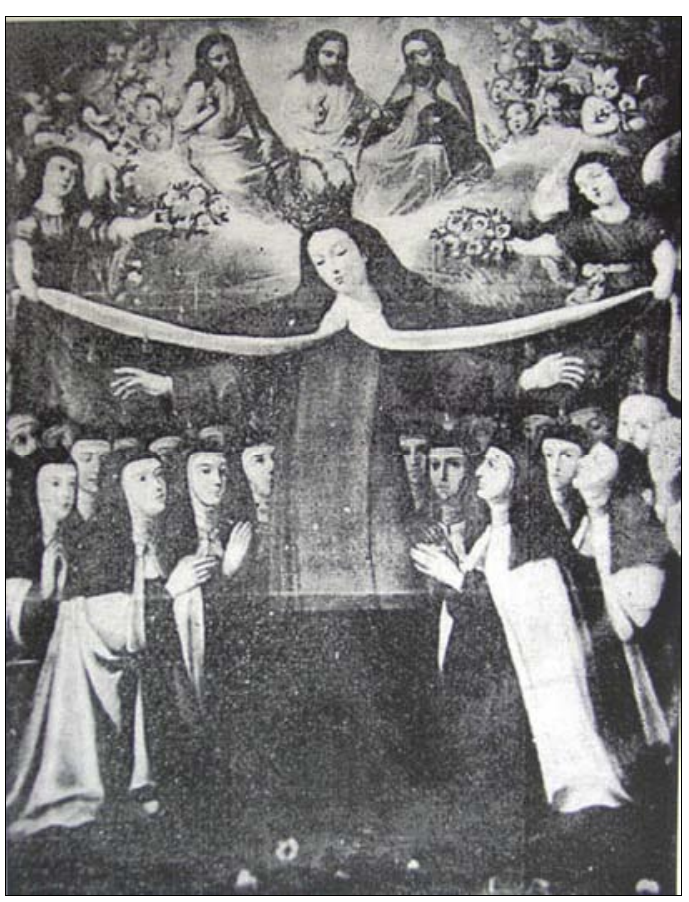

- Lám. 7. "Virgen del Carmen". Atribuido a Isabel de Santiago. Segunda mitad del siglo XVII, primer tercio del XVIII Monasterio del Carmen de San José. Quito. Imagen tomada del libro de de J. M. VARGAS, Arte Quiteño Colonial..., 1944, índice de imágenes: n. LXVI. 


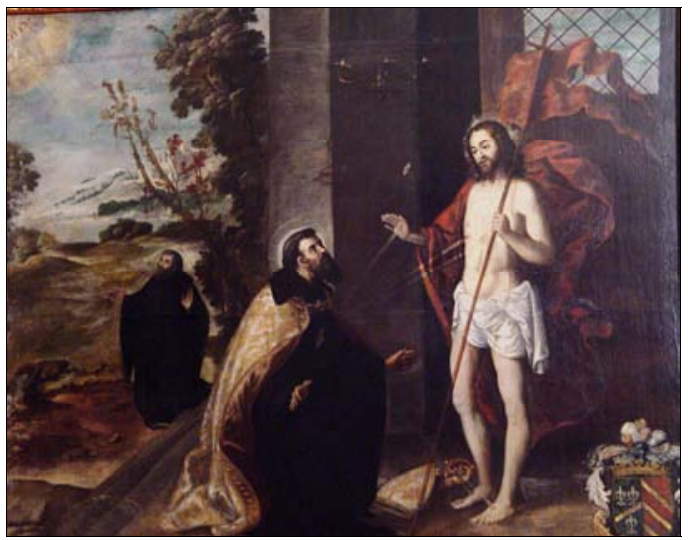

- Lám. 9. “Contemplación mística de San Agustín", 252×216 cm. Atribuida a Miguel de Santiago, ca. 1656. Museo Miguel de Santiago. Convento de San Agustín. Quito. Fotografía de la autora.

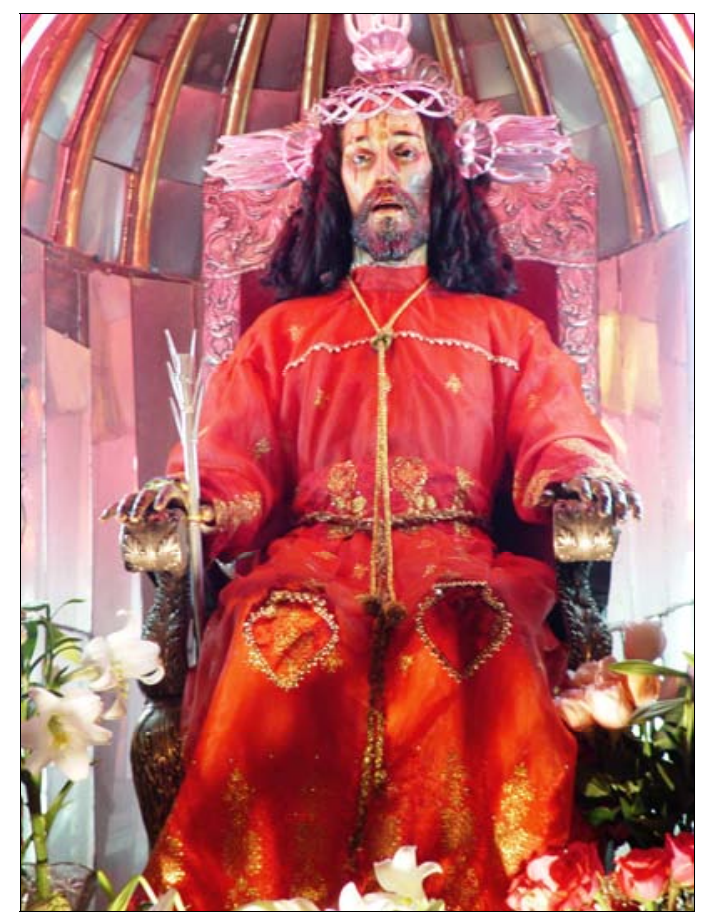

- Lám. 11. "El Señor del Amor", Antonio Egas Venegas, 1699. Iglesia Ntra. Sra. de la Merced. Quito. Fotografía de la autora.

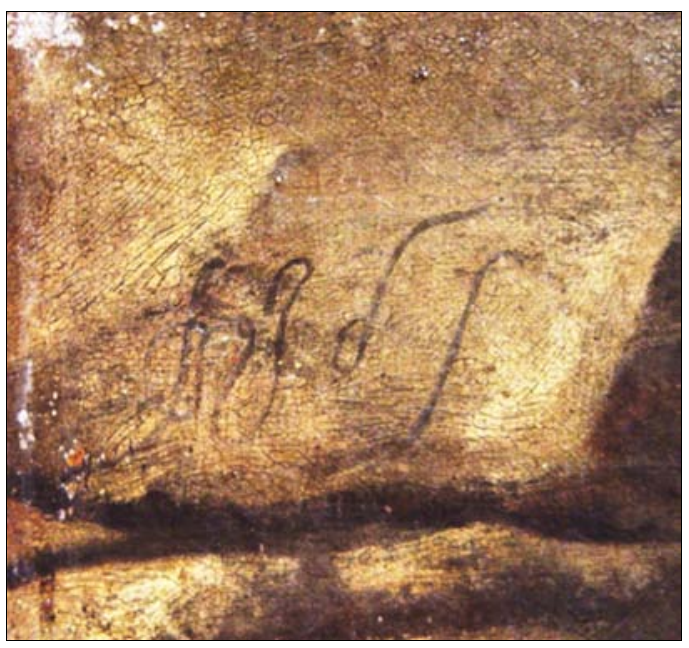

- Lám. 10. Firma estampada sobre una roca en el ángulo inferior izquierdo de "Contemplación mística de San Agustín". Atribuida a Miguel de Santiago, ca. 1656. Museo Miguel de Santiago. Convento de San Agustín. Quito. Fotografía de la autora. 